Prepared in cooperation with the U.S. Army Corps of Engineers

\title{
Power to Detect Trends in Missouri River Fish Populations within the Habitat Assessment Monitoring Program
}

Open-File Report 2010-1011 



\section{Power to Detect Trends in Missouri River Fish Populations within the Habitat Assessment Monitoring Program}

By Janice L. Bryan, Mark L. Wildhaber, and Dan W. Gladish

Prepared in cooperation with the U.S. Army Corps of Engineers

Open-File Report 2010-1011 


\title{
U.S. Department of the Interior \\ KEN SALAZAR, Secretary \\ U.S. Geological Survey \\ Marcia K. McNutt, Director
}

\section{U.S. Geological Survey, Reston, Virginia: 2010}

\author{
For more information on the USGS — the Federal source for science about the Earth, its natural and living resources, \\ natural hazards, and the environment, visit http://www.usgs.gov or call 1-888-ASK-USGS \\ For an overview of USGS information products, including maps, imagery, and publications, \\ visit http://www.usgs.gov/pubprod \\ To order this and other USGS information products, visit http://store.usgs.gov
}

\begin{abstract}
Any use of trade, product, or firm names is for descriptive purposes only and does not imply endorsement by the U.S. Government.

Although this report is in the public domain, permission must be secured from the individual copyright owners to reproduce any copyrighted materials contained within this report.
\end{abstract}

Suggested citation:

Bryan, J.L., Wildhaber, M.L., Gladish, D.W., 2010, Power to detect trends in Missouri River fish populations within the Habitat Assessment Monitoring Program: U.S. Geological Survey Open-File Report 2010-1011, 42 p. 


\section{Contents}

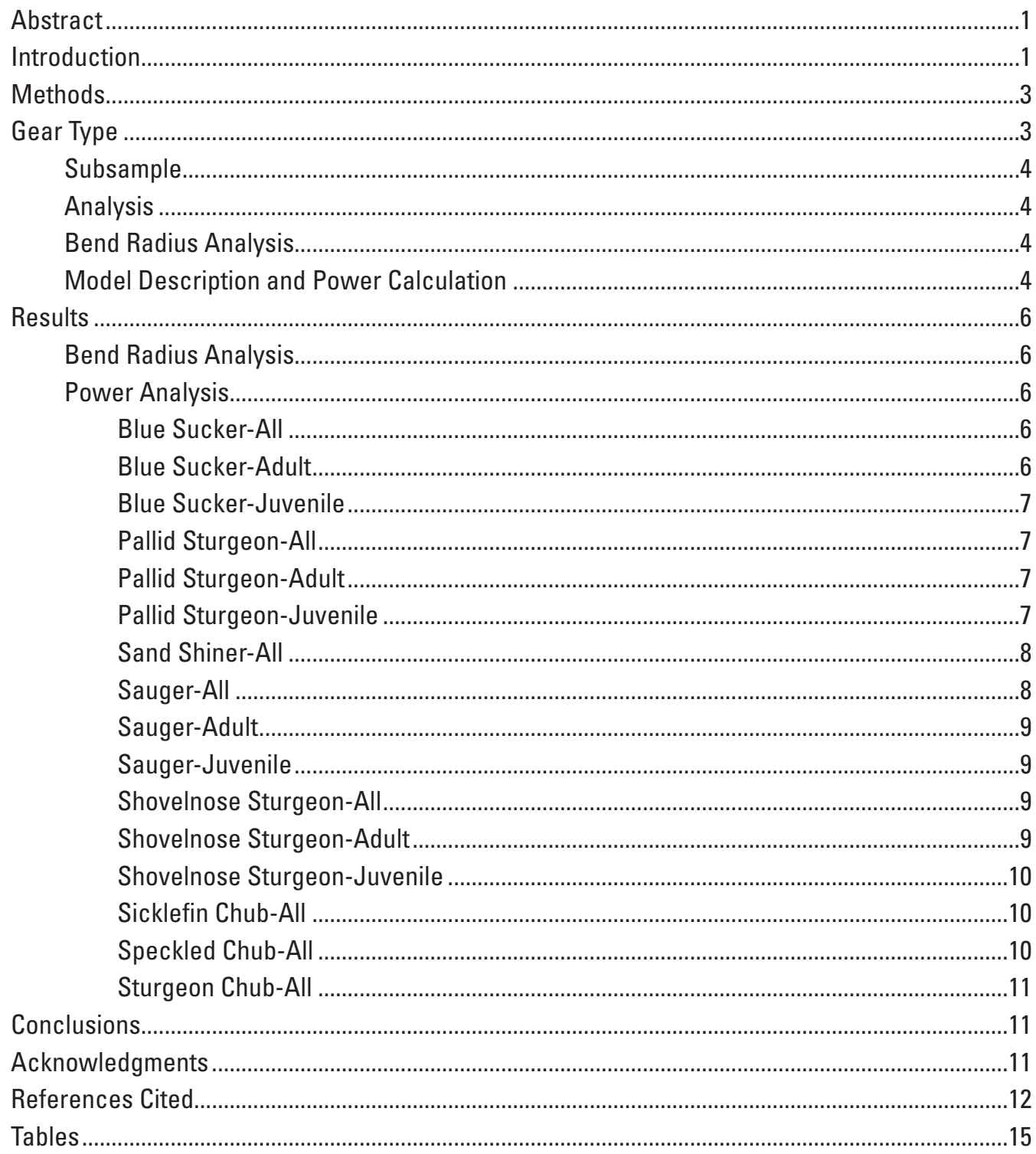

\section{Figures}

1. Map showing the segments designated in the Habitat Assessment Monitoring Program on the Missouri River 


\section{Tables}

1. Nine fish species of interest in the Habitat Assessment Monitoring Program.....

2. Organization of the data collected and analyzed for a gear for each species and their maturity state in the Habitat Assessment Monitoring Program....

3. Summary of the sampling effort during 2006 using three gear types: mini-fyke net, otter trawl, and trammel net.

4. Summary of the bend radius analysis of covariance using shovelnose sturgeon caught in the lower Missouri River.

5. Different groups of data that were removed from the analysis because no fish were caught for that specific factor level

6. Model statistics for all models used in the power analysis...

7. The total count of fish (proportion of non-occurrence in subsamples) and the number of bends the species occupied (proportion of non-occurrence in bends) in the power analysis for each gear type in July 2006

8. The total count of fish (proportion of non-occurrence in subsamples) and the number of bends the species occupied (proportion of non-occurrence in bends) in the power analysis for each gear type in August 2006.

9. The total count of fish (proportion of non-occurrence in subsamples) and the number of bends the species occupied (proportion of non-occurrence in bends) in the power analysis for each gear type in September 2006.

10. Summary of the different bend/subsample levels needed to reach a power of 0.8 when detecting treatment differences in the Habitat Assessment Monitoring Program.

11. Summary of blue sucker-all power, required mean difference, and multiplier needed using current treatment mean difference at different bend/subsample levels for each gear type and month of the Habitat Assessment Monitoring Program.

12. Summary of blue sucker-adult power, required mean difference, and multiplier needed using current treatment mean difference at different bend/subsample levels for each gear type and month of the Habitat Assessment Monitoring Program.

13. Summary of the blue sucker-juvenile power, required mean difference, and multiplier needed using current treatment mean difference at different bend/subsample levels for each gear type and month of the Habitat Assessment Monitoring Program

14. Summary of the pallid sturgeon-all power, required mean difference, and multiplier needed using current treatment mean difference at different bend/subsample levels for each gear type and month of the Habitat Assessment Monitoring Program

15. Summary of the pallid sturgeon-adult power, required mean difference, and multiplier needed using current treatment mean difference at different bend/subsample levels for each gear type and month of the Habitat Assessment Monitoring Program

16. Summary of the pallid sturgeon-juvenile power, required mean difference, and multiplier needed using current treatment mean difference at different bend/subsample levels for each gear type and month of the Habitat Assessment Monitoring Program 
17. Summary of the sand shiner-all power, required mean difference, and multiplier needed using current treatment mean difference at different bend/ subsample levels for each gear type and month of the Habitat Assessment Monitoring Program

18. Summary of the sauger-all power, required mean difference, and multiplier needed using current treatment mean difference at different bend/subsample levels for each gear type and month of the Habitat Assessment Monitoring Program.

19. Summary of the sauger-adult power, required mean difference, and multiplier needed using current treatment mean difference at different bend/subsample levels for each gear type and month of the Habitat Assessment Monitoring Program.

20. Summary of the sauger-juvenile power, required mean difference, and multiplier needed using current treatment mean difference at different bend/subsample levels for each gear type and month of the Habitat Assessment Monitoring Program

21. Summary of the shovelnose sturgeon-all power, required mean difference, and multiplier needed using current treatment mean difference at different bend/subsample levels for each gear type and month of the Habitat Assessment Monitoring Program

22. Summary of the shovelnose sturgeon-adult power, required mean difference, and multiplier needed using current treatment mean difference at different bend/subsample levels for each gear type and month of the Habitat Assessment Monitoring Program

23. Summary of the shovelnose sturgeon-juvenile power, required mean difference, and multiplier needed using current treatment mean difference at different bend/subsample levels for each gear type and month of the Habitat Assessment Monitoring Program

24. Summary of the sicklefin chub-all power, required mean difference, and multiplier needed using current treatment mean difference at different bend/subsample levels for each gear type and month of the Habitat Assessment Monitoring Program

25. Summary of the speckled chub-all power, required mean difference, and multiplier needed using current treatment mean difference at different bend/subsample levels for each gear type and month of the Habitat Assessment Monitoring Program

26. Summary of the sturgeon chub-all power, required mean difference, and multiplier needed using current treatment mean difference at different bend/subsample levels for each gear type and month of the Habitat Assessment Monitoring Program 


\section{Conversion Factors}

Inch/Pound to SI

\begin{tabular}{lcl}
\hline \multicolumn{1}{c}{ Multiply } & By & \multicolumn{1}{c}{ To obtain } \\
\hline inch (in.) & Length & \\
inch (in.) & 2.54 & centimeter $(\mathrm{cm})$ \\
foot (ft) & 25.4 & millimeter $(\mathrm{mm})$ \\
mile (mi) & 0.3048 & meter $(\mathrm{m})$ \\
mile, nautical (nmi) & 1.609 & kilometer $(\mathrm{km})$ \\
yard $(\mathrm{yd})$ & 1.852 & kilometer $(\mathrm{km})$ \\
\hline & 0.9144 & meter $(\mathrm{m})$ \\
acre & Area & \\
acre & 4,047 & square meter $\left(\mathrm{m}^{2}\right)$ \\
acre & 0.4047 & hectare $($ ha) \\
acre & 0.4047 & square hectometer $\left(\mathrm{hm}^{2}\right)$ \\
square foot $\left(\mathrm{ft}^{2}\right)$ & 0.004047 & square kilometer $\left(\mathrm{km}^{2}\right)$ \\
square foot $\left(\mathrm{ft}^{2}\right)$ & 929.0 & square centimeter $\left(\mathrm{cm}^{2}\right)$ \\
square inch $\left(\mathrm{in}^{2}\right)$ & 0.09290 & square meter $\left(\mathrm{m}^{2}\right)$ \\
section $\left(640 \mathrm{acres}^{2}\right.$ or 1 square mile) & 6.452 & square centimeter $\left(\mathrm{cm}^{2}\right)$ \\
square mile $\left(\mathrm{mi}^{2}\right)$ & 259.0 & square hectometer $\left(\mathrm{hm}^{2}\right)$ \\
square mile $\left(\mathrm{mi}^{2}\right)$ & 259.0 & hectare $($ ha) \\
& 2.590 & square kilometer $\left(\mathrm{km}^{2}\right)$ \\
\hline
\end{tabular}




\title{
Power to Detect Trends in Missouri River Fish Populations within the Habitat Assessment Monitoring Program
}

\author{
By Janice L. Bryan', Mark L. Wildhaber', and Dan W. Gladish²
}

\section{Abstract}

As with all large rivers in the United States, the Missouri River has been altered, with approximately one-third of the mainstem length impounded and one-third channelized. These physical alterations to the environment have affected the fish populations, but studies examining the effects of alterations have been localized and for short periods of time, thereby preventing generalization. In response to the U.S. Fish and Wildlife Service Biological Opinion, the U.S. Army Corps of Engineers (USACE) initiated monitoring of habitat improvements of the Missouri River in 2005. The goal of the Habitat Assessment Monitoring Program (HAMP) is to provide information on the response of target fish species to the USACE habitat creation on the Lower Missouri River. To determine the statistical power of the HAMP and in cooperation with USACE, a power analysis was conducted using a normal linear mixed model with variance component estimates based on the first complete year of data. At a level of 20/16 (20 bends with 16 subsamples in each bend), at least one species/month/ gear model has the power to determine differences between treated and untreated bends. The trammel net in September had the most species models with adequate power at the 20/16 level and overall, the trammel net had the most species/month models with adequate power at the 20/16 level. However, using only one gear or gear/month combination would eliminate other species of interest, such as three chub species (Macrhybopsis meeki, Macrhybopsis aestivalis, and Macrhybopsis gelida), sand shiners (Notropis stramineus), pallid sturgeon (Scaphirhynchus albus), and juvenile sauger (Sander canadensis). Since gear types are selective in their species efficiency, the strength of the HAMP approach is using multiple gears that have statistical power to differentiate habitat treatment differences in different fish species within the Missouri River. As is often the case with sampling rare species like the pallid sturgeon, the data used to conduct the analyses exhibit some departures from the parametric model assumptions. However,

${ }^{1}$ U.S. Geological Survey, Columbia Environmental Research Center, 4200 New Haven Road, Columbia, Missouri, 65201.

\footnotetext{
${ }^{2}$ University of Missouri-Columbia, Department of Statistics, 146 Middlebush Hall, Columbia, Missouri, 65211-6100.
}

preliminary simulations indicate that the results of this study are appropriate for application to the HAMP study design.

\section{Introduction}

The Missouri River is 4,180 kilometers (km, 2,597 miles) long (Galat and others, 2005a) and drains one-sixth of the contiguous United States $\left(1,396,117 \mathrm{~km}^{2}\right.$; fig. 1). The drainage basin includes parts of 10 states and two Canadian provinces; 70.3 percent of the basin drains the semi-arid Great Plains physiographic province (Galat and others, 2005a). As with all large rivers in the United States, the Missouri River channel has been substantially altered, with approximately one-third of the mainstem length impounded and one-third channelized [1960 river miles for the Missouri River, U.S. Army Corps of Engineers (USACE); 1999 National Hydrography Dataset, U.S. Geological Survey (USGS), and U.S. Environmental Protection Agency]. The Missouri River sustains the largest reservoir system in the United States with six large mainstem reservoirs in North and South Dakota and Montana. The lower $1,300 \mathrm{~km}$ has no mainstem reservoirs, but the lower 1,204 km riverine channel has been extensively modified and channelized (Galat and others, 2005a).

In the lower Missouri River, physical riverine habitat alterations and floodplain land-use practices (Hesse and others, 1989; Pinter, 2005) have changed the riverine habitat diversity and channel geometry (Hesse and Sheets, 1993; Hallberg and others, 1979). In certain areas, constriction of the channel by levees and channel-training structures has resulted in increases of flood elevations of as much as 3 to 4 meters (m) in the last century (Criss and Shock, 2001; Pinter and Heine, 2005; Ehlmann and Criss, 2006). In other areas, the river bed has degraded due to engineering modifications and dredging (Jacobson and others, 2009). Mainstem reservoirs also have altered discharge variation (Galat and Lipkin, 2000; Pegg and others, 2003), and in combination with channelization, reduced suspended sediment concentration or load more than 70 percent (Blevins, 2006, 70 to 80 percent concentration reduction; Jacobson and others, 2009, 83 to 99.8 percent load reduction). 


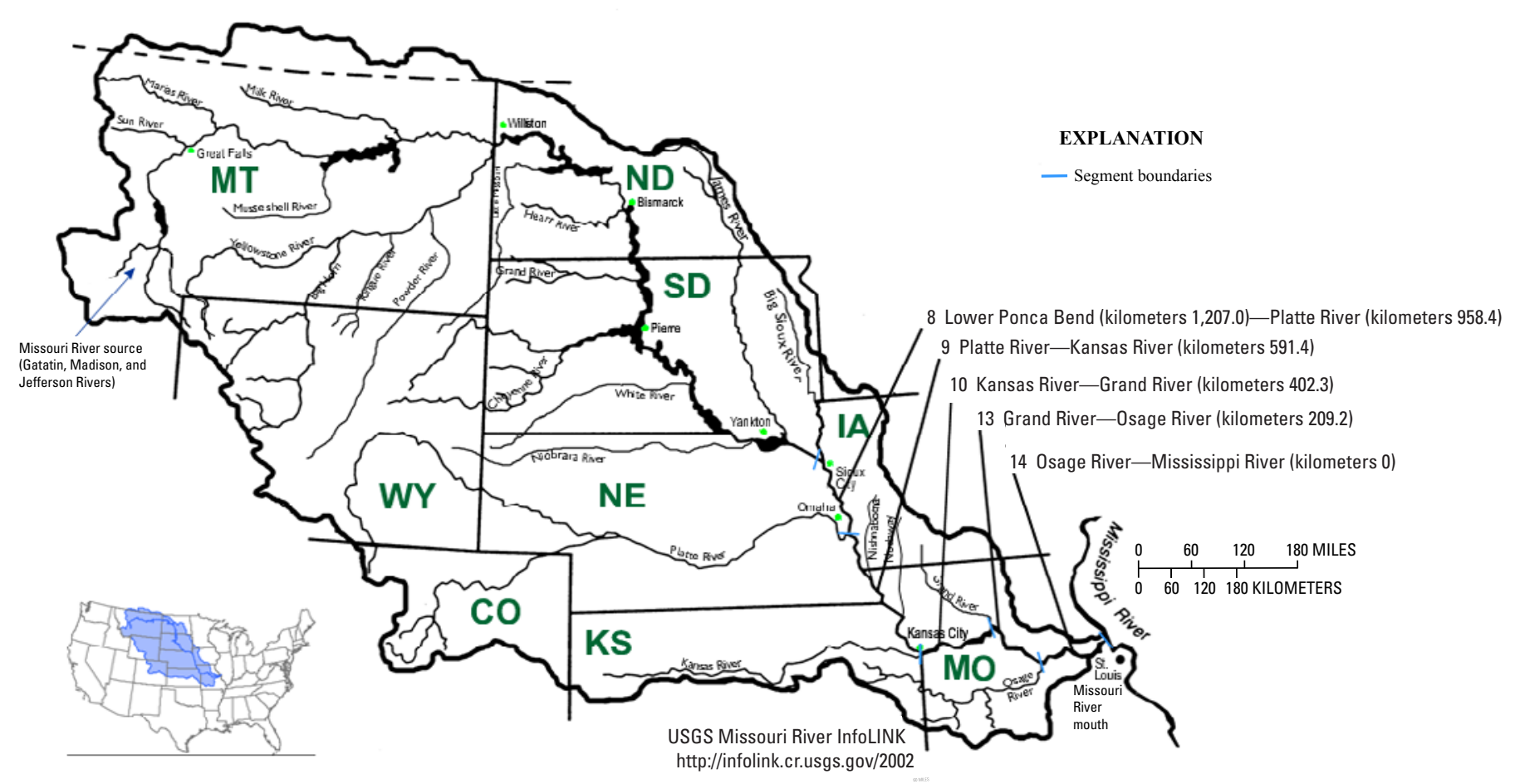

Figure 1. The segments designated in the Habitat Assessment Monitoring Program on the Missouri River.

Physical alterations of the Lower Missouri River have been associated with biological consequences including decreases in fish populations (Pflieger and Grace, 1987; Hesse and Sheets, 1993; Hesse, 1996), decreases in Missouri River floodplain native flora and fauna (Whitmore and Keenlyne, 1990), and a decrease in aquatic benthic insect production as indicated by a decrease of 61 percent in a backwater area downstream from the Niobrara River confluence (Mestl and Hesse, 1993). Although physical changes have received the most attention, they have been accompanied by other potential stressors such as increases in chemical contaminants (Petty and others, 1995, 1998; Meade, 1995) and the introduction of nonnative species (currently 20 percent of fish species for the entire basin, Galat and others, 2005b).

In response to the U.S. Fish and Wildlife Service (USFWS; U.S. Fish and Wildlife Service, 2000, 2003), the USACE initiated construction and monitoring of habitat in the Missouri River as a "Reasonable and Prudent Alternative". The goal of the Habitat Assessment Monitoring Program (HAMP) is to monitor physical and biological responses to the USACE habitat creation actions. Habitat creation has focused on efforts to increase the channel topwidth and habitat complexity by notching wing dikes, disconnectiong dikes from the bank, lowering portions of dikes, and constructing new dike structures to re-align flow (http://www.moriverrecovery.org/ mrrp/f? $p=136: 131: 3068441738170982:: N O:::)$. Through the HAMP (with technical assistance from the USGS and in cooperation with the USACE), selected state and federal agencies (Missouri Department of Conservation, Nebraska
Game and Parks Commission, and USFWS-Columbia National Fish and Wildlife Conservation Office) sampled river bends from the Lower Missouri River (1,204 km) beginning in 2004. By 2006, the program had included bends upstream and downstream in the sampling from Kansas City, Missouri. The HAMP focuses on nine Missouri River benthic community fish species (table 1, at the back of this report). These species and their Missouri River populations represent the Missouri River native benthic fish community, or are species with populations under conservation concern, or both.

To produce the most efficient and effective sampling possible in the HAMP, a power analysis was suggested by the Sustainable Ecosystem Institute (SEI) in their independent science reviews (Sustainable Ecosystem Institute, 2005, 2007). The purpose of the power analysis is to determine the most efficient combination of numbers of bends and gear deployments within a bend to detect differences between treated and untreated bends. Previous studies have examined the power to detect differences in treatments using a mixed model approach (Murray, 1998; Littell and others, 2006). Typically, testing for trends proceeds using a $t$-test on the fixed effect for trend with the proper variance term obtained from the model (Sims and others, 2006). A previous study by Bryan and others (in press) used an Analysis of Variance (ANOVA) with an F-distribution to determine the power of the Pallid Sturgeon Population Assessment Program (PSPAP) with a nested experimental design. Using the same approach, we took advantage of the HAMP nested sampling design (table 2, at the back of this report) and conducted a power analysis using a standard 
ANOVA formulation with multiple fixed effects (universe, bend radius, and treatment) and nested random effects (gear deployment within bend), which results in a $F$-test for the main effect due to treatment. Note when only two levels are considered, the $F$-test and the $t$-test are the same (Neter and others, 1996).

Since the HAMP sampling design assumes bend radius is an important factor in selection of sampling bends, we also conducted an analysis to test this hypothesis. This analysis examines the catch of shovelnose sturgeon (Scaphirhynchus platorynchus) from the PSPAP and whether catch varies with degrees of radius of river bend curvature.

\section{Methods}

The following summarizes the HAMP methods relevant to the power analysis. The HAMP has design features and methodology that are similar to the PSPAP (Drobish, 2005a). More detail is given in the HAMP standard operating procedures (Sampson and Drobish, written commun., 2008). Specifically, the Missouri River is divided into multiple segments (fig. 1) because of the general physical characteristics and human modifications, and the segments are similar to those used in the Missouri River Benthic Fishes Study (Berry and others, 2004). These segments are defined by changes in physical attributes such as water temperature, turbidity, degrading or aggrading stream bed, stream gradient, natural hydrograph, spillway releases, and flow fluctuations (Drobish, 2005a). Only part of the lower Missouri River is channelized; consequently, the HAMP contains bends from downstream of river kilometer 1,207 (Sampson and Drobish, written commun., 2008).

Due to the longitudinal variation in the Missouri River, this program was divided into two different universes. The upper universe is segments 8 and 9 , the lower universe is segments 10, 13, and 14 (fig. 1). In each universe and segment, a set of bends was designated for sampling. In this program, a river bend is the experimental unit, or scale, at which the measurements are replicated. A river bend is defined as "beginning at the origin of each channel crossover and will include the adjacent downstream outside bend/inside bend complex" (Drobish, 2005a). This includes any islands, secondary channels, and tributary mouths. The initial bend selection was developed to randomly represent each treatment; consequently, it is considered as a random variable for this analysis.

Sampling year began on October 31 of the preceding calendar year and ended on October 30 of the present calendar year (for example, the 2006 year would have begun on October 31,2005 , and ended on October 30, 2006). For this analysis, data collected only from year 2006 were used in the analysis.

In the HAMP, three types of bends received structure modification: control, before/after, and impact. The control bends do not have any modifications to the dikes (for example, lowered, partial removal or the addition of new dike structures), and are maintained normally. The impact bends were modified before the study began. The before/after bends are currently in the 'before' portion of HAMP, and at some time will be modified in the future. Consequently, in calculating the variance components, the control and before/ after bends were combined into one non-treatment group and the impact bends are the treatment group. This gives variance components and mean differences that estimate the difference between the two treatment groups. Assuming the before/after group will be the same as the impact group at the end of the study, this difference between the nontreatment and treatment groups represents the difference between the control and impact bends at the beginning of the study or the control and the before/after bends at the end of the study.

The last factor that was used in HAMP is a physical characteristic of a bend, the radius of curvature. Each bend chosen was from two radius categories: 25 th percentile radius and 75 th percentile radius. The 25 th percentile level is when the curvature of the bend was in the 25th percentile or below of all bends in the channelized Missouri River. The 75th percentile radius level was designated when the curvature of the bend was in the 75th percentile or above of all bends.

\section{Gear Type}

Within each bend, different habitats are sampled using specific standard gear types implemented with the same methodology as PSPAP (Sampson and Drobish, written commun., 2008). Only the standard gears that were deployed consistently throughout year 2006 were used in this study. Active gears included otter trawl (OT), and trammel net (TN) whereas passive gears included gill net (GN) and mini-fyke net (MF) (Drobish, 2005b, for details on gear specifications). Active gears moved toward the fish, whereas fish moved toward the net in the passive gears. Hoop nets, beach seines, or beam trawls were not included in our analysis because of the inconsistent use of these gears throughout the months. All standard gears were not used consistently among universe, radius, or treatment. Consequently, HAMP was only fully implemented in 2006 for all factors (universe, radius, and treatment) during July through September using OT and TN and August through September in the upper universe using MF. Our analysis is restricted to these months and gears. For this analysis, we assume that gear efficiency remained constant during all sampling conditions.

Following Berry and others (2004) and Arab and others (2008), the unit of measure for all active gears was catch per unit area (CPUA). In this report, CPUA for each active gear deployment was based on the minimum deployment area of that gear. This scalar is unique to each gear type and was used in this analysis. The minimum deployment area for an OT was $360 \mathrm{~m}^{2}$ (square meters) or $4.9 \mathrm{~m}$ wide by $75 \mathrm{~m}$ long and TN was $2,858 \mathrm{~m}^{2}$ or $38.1 \mathrm{~m}$ wide by $75 \mathrm{~m}$ long. Consequently, the scalar for the OT was 360 and TN was 2,858 . Twelve TN 
deployments were not at the standard width of $38.1 \mathrm{~m}$ and one TN deployment was not at the standard length of $75 \mathrm{~m}$; these samples were removed from the analysis.

The unit of measure for all passive gears was catch per unit effort (CPUE) based on time. The CPUE for each passive gear deployment was based the minimum deployment time. For both gears this was 12 hours; consequently, the scalar for MF and GN was 12 . Sixty MF and one GN deployments did not have a recorded stop time and four MF deployments did not have a recorded start time; these samples were removed from the analysis.

\section{Subsample}

Each gear deployment in a bend was considered a subsample. For each gear type, the subsamples were dispersed evenly throughout the bend.

\section{Analysis}

A separate analysis was performed for each fish species. If mature and juvenile fish were caught (table 1), then additional analyses were performed separately for each maturity size for each species. Following Berry and others (2004), no analyses were conducted on Hybognathus spp. [plains minnow (H. placitus), and western silvery minnow (H. argyritis)] because of difficulties in identifying individual species and because individual species tended to be zoogeographically separated.

Within each month and species, the same set of criteria used by Berry and others, (2004) was used to filter the data for the different levels of analysis. The criteria were applied to the data to provide a consistent decision process for statistical analysis for each species. In addition, imposing the criteria helps provide a set of data that are closer to satisfying the parametric model assumptions (for example, normality and homoskedastic variance), although some departures from the assumptions still remain. The criteria were applied to all gear deployments that had no missing variables or information. Due to the structured experimental design of this study, the criterion that removed data that occurred less than 5 percent of the time was not used for this analysis. The only criterion used was that one fish had to be collected for a given month, universe, radius, or gear to be included in the analysis. If no fish were caught in one treatment level, but some in the other, the power analysis assumed the zero was real. If in the future this assumption proves false, the power analysis presented in this report will be overestimated; consequently, the results from these results should be interpreted with caution as denoted in the accompanying tables by superscripts.

\section{Bend Radius Analysis}

To examine whether bend radius should be a grouping factor in the HAMP analysis, the PSPAP catch data were analyzed using bend radius as a predictor variable. In the analysis of the PSPAP data, the shovelnose sturgeon captures were used only because all species had non-normal distributions, and only the shovelnose sturgeon distribution was close enough to normal for an analysis (Scheffe, 1959; Milliken and Johnson, 1984). We only included catches using OT, TN and GN from segments 8, 9, 10, 13, 14 and years 2003-2005. The data used in this analysis were used in a previous power analysis (Bryan and others, in press), which includes all data methodology involving CPUA and CPUE calculations and deletions due to lack of species catch for specific gear types.

To examine the relation of shovelnose sturgeon catch to bend radius in the PSPAP data, an Analysis of Covariance model (ANCOVA) with bend radius as the continuous variable was used. Bend radius was a continuous variable in the PSPAP data because all bends were used, not just the two levels used in HAMP sampling design. Designating bend radius as a continuous variable will allow the determination of whether bend radii is important in the trends of fish catch data, and warrant use as a grouping factor in the HAMP sampling design. Year, season, and segment were initially used as discrete factors in the ANCOVA model but a significant interaction of segment and radius occurred. This violated the assumption of equal slopes required for an ANCOVA model. Therefore, a separate ANCOVA was used for each segment with bend radius as the continuous variable and year and season as the discrete factors, where appropriate (not all years and seasons were sampled for each gear, Bryan and others, in press). The normal distribution assumption was tested with a Shapiro-Wilk test and the response variable was $\log _{10}$ transformed to meet the test assumptions.

\section{Model Description and Power Calculation}

The HAMP sampling design has a nested structure with multiple subsamples within each bend (table 2). This nested structure is similar to the PSPAP, and the model used in the HAMP power analysis was based on the model for the PSPAP power analysis (Bryan and others, in press). Specifically, for each species and month, the HAMP model consisted of three fixed effects (universe, radius, and treatment). Additionally, within each universe, radius, and treatment combination, a random sample of river bends was selected. Further, within each river bend, multiple gear deployments (subsamples) were distributed randomly across the area within a bend. Separate analyses calculated the power for each of the different combinations of species, month, and gear type.

To calculate the power of higher levels of effort than were observed in the original data, requires knowledge of the population variances associated with the random effects due to bend and subsample. Ultimately these population variances were inferred based on variance components obtained from the data, and are considered known when calculating power. 
To accommodate the study design, this power analysis is based on the normal linear mixed model given by:

$Y_{i j k l m}=\mu+\alpha_{i}+\beta_{j}+\gamma_{k}+\alpha \beta_{i j}+\alpha \gamma_{i k}+\beta \gamma_{j k}+\alpha \beta \gamma_{i j k}+D_{i j k l}+S_{i j k l m}$

where

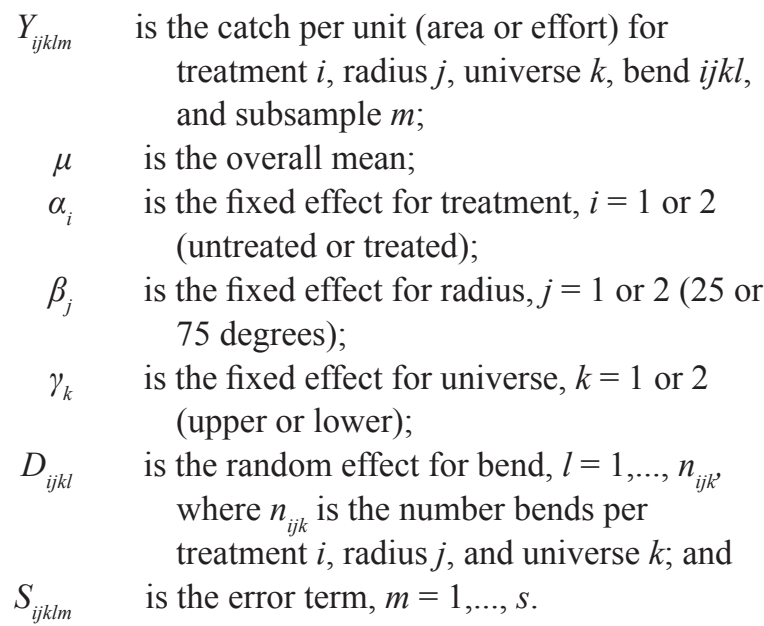

Further, we assume $D_{i j k l} \sim$ iid $N\left(0, \sigma_{D}^{2}\right)$ and $S_{i j k m} \sim$ iid $N\left(0, \sigma_{S}^{2}\right)$, with $D_{i j k l}$ and $S_{i j k l m}$ mutually independent; see Kuehl (2000) for a comprehensive discussion. For the treatment group, there are $n_{1}$. number of bends. For the non-treatment group, there are $n_{2} .$. number of bends. The value of $n_{1}$. and $n_{2} .$. varies depending on the model. Define $M S \alpha$ as the mean square for treatment and $M S D$ as the mean square for bend. The F-distribution test statistic for testing the hypothesis that the treatment and non-treatment groups are different is:

$$
F=\frac{M S \alpha}{M S D}
$$

Thus, the power of the test is:

$$
P\left(F>F_{1-\alpha ; a-1,\left(n_{1} \ldots+n_{2} . .\right)-a b c} \mid \varphi\right)
$$

where

$$
\begin{gathered}
\varphi=\frac{s}{\sigma_{S}^{2}+s \sigma_{D}^{2}} \sum_{i=1}^{a} n_{i} . .\left(\bar{\mu}_{i} . .-\bar{\mu}_{\ldots} . .\right)^{2}= \\
\frac{s}{\sigma_{S}^{2}+s \sigma_{D}^{2}}\left[n_{1} . .\left(\bar{\mu}_{1} . .-\bar{\mu}_{\ldots} . .\right)^{2}+n_{2} . .\left(\bar{\mu}_{2} . .-\bar{\mu}_{\ldots} . .\right)^{2}\right]
\end{gathered}
$$

is the non-centrality parameter. Note, since only two treatments exist, $\left(\bar{\mu}_{1} . .-\bar{\mu}_{\ldots} \ldots\right)^{2}=\left(\bar{\mu}_{2} . .-\bar{\mu}_{\ldots} .\right)^{2}, \varphi$ simplfies further:

$$
\begin{gathered}
\varphi=\frac{s}{\sigma_{S}^{2}+s \sigma_{D}^{2}}\left[n_{1} . .\left(\bar{\mu}_{1} . .-\bar{\mu}_{\ldots} .\right)^{2}+n_{2} . .\left(\bar{\mu}_{2} . .-\bar{\mu}_{\ldots} . .\right)^{2}\right]= \\
\frac{s\left(n_{1} . .+n_{2} . .\right)\left(\bar{\mu}_{1} . .-\bar{\mu}_{\ldots} . .\right)^{2}}{\sigma_{S}^{2}+s \sigma_{D}^{2}}
\end{gathered}
$$

To determine the difference in the means needed at a power of 0.8 , we rearranged the equation above to the following:

$$
\bar{\mu}_{1} . .-\bar{\mu}_{2} . .=2 \sqrt{\frac{\varphi\left(\sigma_{S}^{2}+s \sigma_{D}^{2}\right)}{s\left(n_{1} . .+n_{2} . .\right)}}
$$

where $\varphi$ is calculated using the noncentrality function in SAS (version 9.1.3; Littell and others, 2006) that calculates the parameter using an F distribution and a probability of 0.2 and a F critical value with the same degrees of freedom used in the power calculation.

As an exploratory measure, the variance components for all models were initially estimated using Restricted Maximum Likelihood (REML) using the "unbound" option in the Mixed Proceedure in SAS. Models having a negative bend variance component estimate were noted and then re-estimated using standard REML estimation methods (that is, the variance components have a bounded parameter space and are restricted to be greater than or equal to zero). The re-estimated value was then used in the power calculation. The negative variance component estimates in the exploratory analysis argues for the collection of additional data to be analyzed in conjunction with the existing data in the belief that increased information will produce positive bend variance component estimates, even when the parameter space is unbounded (Kuehl, 2000). Even though the variance component estimates were estimated using REML, any model results having an initially negative bend variance component estimate (from the exploratory phase of the analysis) should be interpreted with caution (as denoted in the accompanying tables).

The target level of effort for the 2006 sampling year for HAMP was 4 bends with 8 subsamples per bend for each combination of month/universe/radius/treatment/gear type [hereafter referred to as $4 / 8$ or number of bends/number of subsamples per bend (Sampson and Drobish, written commun., 2008)]. However, in the data used for the power analysis, these levels fluctuated slightly between months, universes, radii, and treatments (table 3, at the back of this report); consequently, for this analysis the levels of effort tested were set at $4 / 8$ and above in a balanced design. The levels of bend effort tested in each treatment were 4, 20, 40, 80, and subsample effort levels of $4,8,12$, and 16 . The first bend level was calculated using 4 bends for each of the two universes, two radii, and two treatments, then multiplying this level by $5,10,15$, and 20 . These levels represent years of sampling for each month assuming the variation in the current data are similar to the future years. Other topics of interest that were examined include the CPU difference required under the different levels of effort to achieve an adequate power of 0.8 at different levels of effort for each gear type and month and the multiplier needed to achieve adequate power using the current (2006) mean difference for different levels of effort for each gear type and month. For all tests the $\alpha$-level was 0.05 , and a power of 0.80 was considered adequate. 


\section{Results}

\section{Bend Radius Analysis}

The TN model in segment 8 violated all assumptions for the ANCOVA model, so no analysis was conducted. Due to the low numbers of shovelnose sturgeon captured, the GN ANCOVA model in segment 8 and 10 was not conducted. Five of the 12 ANCOVA models did not meet the normality assumption (table 4, at the back of this report), but did have high Shapiro-Wilk test statistics, indicating data that are close to normal (Scheffe, 1959; Milliken and Johnson, 1984).

The mean bend radius was a significant factor in the ANCOVA model in segments 9 and 14, accounting for 9.01 to 21.49 percent of the variation in the model, respectively (table 4). The mean bend radius was a marginally significant factor in the ANCOVA model for segment 8, accounting for 8.52 percent of the variation. Mean bend radius accounted for less than 2 percent of the variation in the ANCOVA models for segments 10 and 13 .

\section{Power Analysis}

Each individual species and size category was susceptible to certain gear types with high percentages of non-occurrence. The high incidence of zeros for the species/gear combinations required the removal of 93 species/month/universe/radius/gear combinations from the analysis because of deletion criteria (table 5, at the back of this report). Of the models tested, 36 out of 78 models had a negative bend variance component estimate (based on preliminary exploratory analysis) and were recalculated using standard REML estimation, which restricts variance component estimates to be greater than or equal to zero (table 6, at the back of this report). Twenty-one out of 78 models had either a control or treatment mean of zero (table 6). Because of the high frequency of zero in the data (tables $7-9$, at the back of this report), the distributions were not normally distributed. However, based on preliminary simulation results, the power increased as the number of zeros decreased and, therefore, the assumption of normality was violated to a lesser degree (J. Bryan, U.S. Geological Survey, unpub. data, 2008; D. Gladish, University of Missouri-Columbia, unpub. data, 2009). Consequently, this indicates the power estimates presented are conservative.

At a level of 4 bends and 8 subsamples, only the pallid sturgeon-adult model had adequate power to detect a difference between the treatment groups (table 10, at the back of this report). At a level of 20 bends and at various levels of subsamples, 26 species/gear/month models had adequate power to detect a difference between the treatment groups. At least one model with adequate power for each gear/month/species combination existed. At the level of 40 bends and at various levels of subsamples, an additional 16 species/gear/month models had adequate power to detect a difference. At a level of 80 bends and at various levels of subsamples, an additional 6 species/gear/month models had adequate power. Twentynine species/gear/month models did not have adequate power at a level of 80 bends and 16 subsamples.

\section{Blue Sucker-All}

- The OT and TN in all 3 months had adequate catch to meet our criteria and calculate power values (tables 7-9).

- The lowest level of sampling with adequate power was accomplished using the TN in August (table 11, at the back of this report).

- Using OT, none of the months reached adequate power at the 80/16 level (table 10).

- The TN reached adequate power at the 20/16 and 40/8 level of effort in August and September, respectively (table 10). The TN did not reach adequate power in the month of July.

- Using OT in July would require the mean difference between the treatments to be 248.42 times greater than the current difference to reach adequate power at the current $4 / 4$ level of sampling (table 11). In August and September would require the mean difference between the treatments to be 23.11 and 19.75 times greater than the current difference, respectively.

- Using TN in July would require the mean difference between the treatments to be 10.42 times greater than the current difference to reach adequate power at the current $4 / 4$ level of sampling (table 11). In August and September would require the mean difference between the treatments to be 4.80 and 3.61 times greater than the current difference, respectively.

\section{Blue Sucker-Adult}

- The OT and TN in all 3 months had adequate catch to meet our criteria and calculate power values (tables 7-9).

- The lowest level of sampling with adequate power was accomplished using the TN in August (table 12, at the back of this report).

- The OT reached adequate power at the 40/16 level of effort in August (table 10). The OT did not reach adequate power in the month of July or September. 
- The TN reached adequate power at the 20/16 level of effort in August (table 10). The TN did not reach adequate power in the month of July or September.

- Using OT in July would require the mean difference between the treatments to be 67.55 times greater than the current difference to reach adequate power at the current $4 / 4$ level of sampling (table 12). In August and September would require the mean difference between the treatments to be 6.28 and 47.91 times greater than the current difference, respectively.

- Using TN in July would require the mean difference between the treatments to be 10.59 times greater than the current difference to reach adequate power at the current $4 / 4$ level of sampling (table 12). In August and September would require the mean difference between the treatments to be 4.80 and 7.85 times greater than the current difference, respectively.

\section{Blue Sucker-Juvenile}

- The OT in all 3 months and the TN in July and September had adequate catch to meet our criteria and calculate power values (tables 7-9).

- The lowest level of sampling with adequate power was accomplished using the TN in September (table 13 , at the back of this report).

- The OT reached adequate power at the 20/16 level of effort in August and September (table 10). The OT did not reach adequate power in the month of July.

- The TN reached adequate power at the $20 / 8$ level of effort in September (table 10). The TN did not reach adequate power in the month of July.

- Using OT in July would require the mean difference between the treatments to be 19.00 times greater than the current difference to reach adequate power at the current $4 / 4$ level of sampling. (table 13). In August and September would require the mean difference between the treatments to be 4.30 and 5.03 times greater than the current difference, respectively.

- Using TN in July would require the mean difference between the treatments to be 30.54 times greater than the current difference to reach adequate power at the current 4/4 level of sampling (table 13). In September would require the mean difference between the treatments to be 2.68 times greater than the current difference, respectively.

\section{Pallid Sturgeon-All}

- The OT in July and September and the TN in July and August had adequate catch to meet our criteria and calculate power values (tables 7-9).

- The lowest level of sampling with adequate power was accomplished using the OT in July (table 14, at the back of this report).

- The OT reached adequate power at the 20/4 and 40/8 level of effort in July and September, respectively (table 10).

- The TN reached adequate power at the 20/12 and 20/16 level of effort in July and August, respectively (table 10).

- Using OT in July would require the mean difference between the treatments to be 2.18 times greater than the current difference to reach adequate power at the current $4 / 4$ level of sampling. (table 14). In September would require the mean difference between the treatments to be 4.62 times greater than the current difference.

- Using TN in July would require the mean difference between the treatments to be 3.37 times greater than the current difference to reach adequate power at the current $4 / 4$ level of sampling (table 14). In August would require the mean difference between the treatments to be 5.06 times greater than the current difference.

\section{Pallid Sturgeon-Adult}

- The OT in July had adequate catch to meet our criteria and calculate power values (tables 7-9).

- The lowest level of sampling with adequate power was accomplished using the OT in July (table 15, at the back of this report).

- The OT reached adequate power at the $4 / 8$ level of effort in July (table 10).

- Using OT in July would require the mean difference between the treatments to be 1.30 times greater than the current difference to reach adequate power at the current $4 / 4$ level of sampling (table 15).

\section{Pallid Sturgeon-Juvenile}

- The OT in July and September and the TN in July and August had adequate catch to meet our criteria and calculate power values (tables 7-9). 
- The lowest level of sampling with adequate power was accomplished using the TN in July (table 16, at the back of this report).

- The OT reached adequate power at the $40 / 8$ level of effort in September (table 10). The OT did not reach adequate power in the month of July.

- The TN reached adequate power at the $20 / 12$ and 20/16 level of effort in July and August, respectively (table 10).

- Using OT in July would require the mean difference between the treatments to be 160.89 times greater than the current difference to reach adequate power at the current $4 / 4$ level of sampling. (table 16). In September would require the mean difference between the treatments to be 4.62 times greater than the current difference.

- Using TN in July would require the mean difference between the treatments to be 3.37 times greater than the current difference to reach adequate power at the current 4/4 level of sampling (table 16). In August would require the mean difference between the treatments to be 5.06 times greater than the current difference.

\section{Sand Shiner-All}

- The MF in August and September and OT in all 3 months had adequate catch to meet our criteria and calculate power values (tables 7-9).

- The lowest level of sampling with adequate power was accomplished using the OT in September (table 17, at the back of this report).

- The MF reached adequate power at the 40/16 and 80/8 level of effort in September and August, respectively (table 10).

- The OT reached adequate power at the $20 / 8,40 / 8$, and 80/16 level of effort in September, July and August, respectively (table 10).

- Using MF in August would require the mean difference between the treatments to be 5.35 times greater than the current difference to reach adequate power at the current $4 / 4$ level of sampling. (table 17). In September would require the mean difference between the treatments to be 5.09 times greater than the current difference.

- Using OT in July would require the mean difference between the treatments to be 4.53 times greater than the current difference to reach adequate power at the current $4 / 4$ level of sampling (table 17). In August and September would require the mean difference between the treatments to be 9.34 and 3.69 times greater than the current difference, respectively.

\section{Sauger-All}

- The MF, OT and TN for all 3 months had adequate catch to meet our criteria and calculate power values (tables 7-9).

- The lowest level of sampling with adequate power was accomplished using the TN in September (table 18 , at the back of this report).

- The MF reached adequate power at the 20/12 and 40/12 level of effort in August and September, respectively (table 10).

- The OT reached adequate power at the 80/12 level of effort in September (table 10). The OT did not reach adequate power in the month of July and August.

- The TN reached adequate power at the $20 / 8$ and 40/12 level of effort in September and August, respectively (table 10). The TN did not reach adequate power in the month of July.

- Using MF in August would require the mean difference between the treatments to be 3.88 times greater than the current difference to reach adequate power at the current $4 / 4$ level of sampling. (table 18). In September would require the mean difference between the treatments to be 5.12 times greater than the current difference.

- Using OT in July would require the mean difference between the treatments to be 14.29 times greater than the current difference to reach adequate power at the current $4 / 4$ level of sampling (table 18). In August and September would require the mean difference between the treatments to be 28.86 and 7.45 times greater than the current difference, respectively.

- Using TN in July would require the mean difference between the treatments to be 4,692.27 times greater than the current difference to reach adequate power at the current $4 / 4$ level of sampling (table 18). In August and September would require the mean difference between the treatments to be 5.45 and 3.41 times greater than the current difference, respectively. 


\section{Sauger-Adult}

- The OT in August and September and TN in all 3 months had adequate catch to meet our criteria and calculate power values (tables 7-9).

- The lowest level of sampling with adequate power was accomplished using the TN in September (table 19 , at the back of this report).

- The OT reached adequate power at the $40 / 8$ level of effort in September (table 10). The OT did not reach adequate power in the month of August.

- The TN reached adequate power at the $20 / 8$ and 40/12 level of effort in September and August, respectively (table 10). The TN did not reach adequate power in the month of July.

- Using OT in August would require the mean difference between the treatments to be 28.86 times greater than the current difference to reach adequate power at the current $4 / 4$ level of sampling. (table 19). In September would require the mean difference between the treatments to be 4.62 times greater than the current difference.

- Using TN in July would require the mean difference between the treatments to be 4,692.27 times greater than the current difference to reach adequate power at the current $4 / 4$ level of sampling (table 19). In August and September would require the mean difference between the treatments to be 5.45 and 3.41 times greater than the current difference, respectively.

\section{Sauger-Juvenile}

- The MF in August and September and OT in July and September had adequate catch to meet our criteria and calculate power values (tables 7-9).

- The lowest level of sampling with adequate power was accomplished using the MF in August (table 20, at the back of this report).

- The MF reached adequate power at the 20/12 and 40/12 level of effort in August and September, respectively (table 10).

- Using OT, none of the months reached adequate power at the 80/16 level (table 10).

- Using MF in August would require the mean difference between the treatments to be 3.88 times greater than the current difference to reach adequate power at the current $4 / 4$ level of sampling. (table 20). In September would require the mean difference between the treatments to be 5.12 times greater than the current difference.

- Using OT in July would require the mean difference between the treatments to be 14.29 times greater than the current difference to reach adequate power at the current $4 / 4$ level of sampling (table 20). In September would require the mean difference between the treatments to be 13.75 times greater than the current difference.

\section{Shovelnose Sturgeon-All}

- The OT and TN in all 3 months had adequate catch to meet our criteria and calculate power values (tables 7-9).

- The lowest level of sampling with adequate power was accomplished using the TN in September (table 21, at the back of this report).

- The OT reached adequate power at the 20/16 level of effort in July (table 10). The OT did not reach adequate power in the month of August or September.

- The TN reached adequate power at the 20/8 level of effort in September (table 10). The TN did not reach adequate power in the month of July or August.

- Using OT in July would require the mean difference between the treatments to be 4.03 times greater than the current difference to reach adequate power at the current $4 / 4$ level of sampling. (table 21). In August and September would require the mean difference between the treatments to be $6,821.16$ and 9.67 times greater than the current difference, respectively.

- Using TN in July would require the mean difference between the treatments to be 15.25 times greater than the current difference to reach adequate power at the current $4 / 4$ level of sampling (table 21). In August and September would require the mean difference between the treatments to be 12.77 and 2.33 times greater than the current difference, respectively.

\section{Shovelnose Sturgeon-Adult}

- The OT and TN in all 3 months had adequate catch to meet our criteria and calculate power values (tables 7-9).

- The lowest level of sampling with adequate power was accomplished using the TN in August and September (table 22, at the back of this report). 
- The OT reached adequate power at the 40/12, 40/16, and 80/12 level of effort in July, September, and August, respectively (table 10).

- The TN reached adequate power at the $20 / 8$ level of effort in August and September (table 10). The TN reached adequate power at the $40 / 16$ level of effort in July.

- Using OT in July would require the mean difference between the treatments to be 5.65 times greater than the current difference to reach adequate power at the current $4 / 4$ level of sampling. (table 22). In August and September would require the mean difference between the treatments to be 7.97 and 5.95 times greater than the current difference, respectively.

- Using TN in July would require the mean difference between the treatments to be 5.34 times greater than the current difference to reach adequate power at the current $4 / 4$ level of sampling (table 22). In August and September would require the mean difference between the treatments to be 2.39 and 2.49 times greater than the current difference, respectively.

\section{Shovelnose Sturgeon-Juvenile}

- The OT and TN in all 3 months had adequate catch to meet our criteria and calculate power values (tables 7-9).

- The lowest level of sampling with adequate power was accomplished using the OT in July and TN in September (table 23, at the back of this report).

- The OT reached adequate power at the $20 / 8$ and 80/12 level of effort in July and August, respectively (table 10). The OT did not reach adequate power in the month of September.

- The TN reached adequate power at the $20 / 8$ and 40/12 level of effort in September and July, respectively (table 10). The TN did not reach adequate power in the month of August.

- Using OT in July would require the mean difference between the treatments to be 2.34 times greater than the current difference to reach adequate power at the current 4/4 level of sampling. (table 23). In August and September would require the mean difference between the treatments to be 6.81 and 16.72 times greater than the current difference, respectively.

- Using TN in July would require the mean difference between the treatments to be 4.65 times greater than the current difference to reach adequate power at the current 4/4 level of sampling (table 23). In August and September would require the mean difference between the treatments to be 12.31 and 2.34 times greater than the current difference, respectively.

\section{Sicklefin Chub-All}

- The OT in all 3 months had adequate catch to meet our criteria and calculate power values (tables 7-9).

- The lowest level of sampling with adequate power was accomplished using the OT in August and September (table 24, at the back of this report).

- The OT reached adequate power at the 20/12 level of effort in August and September (table 10). The OT reached adequate power at the 40/12 level of effort in July.

- Using OT in July would require the mean difference between the treatments to be 5.00 times greater than the current difference to reach adequate power at the current 4/4 level of sampling. (table 24). In August and September would require the mean difference between the treatments to be 3.78 and 3.22 times greater than the current difference, respectively.

\section{Speckled Chub-All}

- The MF in August and September and the OT in all 3 months had adequate catch to meet our criteria and calculate power values (tables 7-9).

- The lowest level of sampling with adequate power was accomplished using the MF in August or OT in July (table 25, at the back of this report).

- The MF reached adequate power at the 20/12 level of effort in August (table 10). The MF did not reach adequate power in the month of September.

- The OT reached adequate power at the 20/12 and 80/16 level of effort in July and August, respectively (table 10). The OT did not reach adequate power in the month of September.

- Using MF in August would require the mean difference between the treatments to be 3.31 times greater than the current difference to reach adequate power at the current $4 / 4$ level of sampling. (table 25). In September would require the mean difference between the treatments to be 12.64 times greater than the current difference.

- Using OT in July would require the mean difference between the treatments to be 3.65 times greater than the current difference to reach adequate power at the current 4/4 level of sampling (table 25). In August and September would require the mean difference 
between the treatments to be 8.01 and 10.08 times greater than the current difference, respectively.

\section{Sturgeon Chub-All}

- The MF in September and the OT in all 3 months had adequate catch to meet our criteria and calculate power values (tables 7-9).

- The lowest level of sampling with adequate power was accomplished using the MF in September (table 26, at the back of this report).

- The MF reached adequate power at the 20/8 level of effort in September (table 10).

- Using OT, none of the months reached adequate power at the 80/16 level (table 10).

- Using MF in September would require the mean difference between the treatments to be 3.21 times greater than the current difference to reach adequate power at the current $4 / 4$ level of sampling. (table 26).

- Using OT in July would require the mean difference between the treatments to be 95.03 times greater than the current difference to reach adequate power at the current $4 / 4$ level of sampling (table 26). In August and September would require the mean difference between the treatments to be 32.52 and 161.93 times greater than the current difference, respectively.

\section{Conclusions}

The mean bend radius was a significant factor in some of the segments and with more than one gear type. Even though a longitudinal pattern did not exist, the significance would indicate that the bend radius does affect the numbers of shovelnose sturgeon for certain segments of the river. This analysis supports the inclusion of the bend radius as a factor in the Habitat Assessment Monitoring Program (HAMP) experimental design.

Because of the absence of species caught in every month and the inconsistency of standard gear deployments in every month, only the power of 3 months and three gears are summarized. The power estimates from this study are conservative since preliminary analyses indicate that a decrease in the number of zeros or increase in the number of fish caught will increase the power of HAMP.

The lowest level of non-occurrence (zero catches) at the bend level for pallid sturgeon was 0.67 using otter trawl (OT) or trammel net (TN) in July or TN in September. This model contains the catch of the only one pallid sturgeon adult collected in this study over three bends (the lowest number of bends for any model used). However, this low catch rate did not prevent the power of the pallid sturgeon-adult OT model in July from being the highest. These results are presented with caution because the models for all pallid sturgeon caught with OT in July were based on bend variance component estimates that were initially negative. This would indicate more data are required for a more accurate variance component estimate. If future efforts focus on using different gear types at different levels, then an update of the results would be desirable because the results from this analysis assume that the variance estimates represent the variance estimates at the end of the study. Because these results are based on 3 months of data collection, updates to this power analysis are recommended after additional data have been aquired.

At a level of 20/16, at least one species/month/gear model has the power to determine differences between treatments. This would be an increase from the current (2006) level of sampling at 4/8. The TN in September had the most species models with adequate power at the 20/16 level. Overall, the $\mathrm{TN}$ had the most species/month models with adequate power at the 20/16 level. If the focus of the HAMP is to sample juvenile species using OT, then an effort level of $20 / 8$ would have sufficient power for at least 1 month for juvenile bluesuckers, juvenile shovelnose sturgeon, sicklefin chub, speckled chub, and sand shiner. To have adequate power, the level of effort would need to increase to $40 / 8$ for the model containing September, OT and juvenile pallid sturgeon. Only using mini-fyke net (MF), sampling at a level of $20 / 8$ would attain adequate power for at least 1 month for juvenile sauger, speckled chub, and sturgeon chub.

However, using only one gear type or gear/month combination would eliminate other species of interest, such as all three chub species, sand shiners, pallid sturgeon, and juvenile sauger. These results show the value of using multiple gear types to monitor the fish community in the Missouri River, which is intuitive result since certain species are more susceptible to specific gear types at certain parts of their life cycle. Another aspect of using multiple gear types to sample a fish community is the ability to combine active gears and passive gears in multi-gear models. Multi-gear power calculations were unable to be calculated because of time constraints. However, with additional data, higher catch rates, and the use of multi-gear models, the power of the HAMP to detect trends in fish populations in the Missouri River will likely improve.

\section{Acknowledgments}

The authors thank all the people that have collected data as part of the HAMP and all the coordinators, and data managers. A special thanks to the Missouri Department of Conservation for assistance with data acquisition and the Nebraska Game and Parks Commission and the USFWS-Columbia National Fish and Wildlife Conservation Office for data 
collection. We also acknowledge the USACE Missouri River Recovery-Integrated Science Program, Yankton, South Dakota as the funding agency. Lastly, thanks to all who helped from the USGS Columbia Environmental Research Center.

\section{References Cited}

Arab, A., Wildhaber, M.L., Wikle, C.K., and Gentry C.N., 2008, Zero-inflated modeling of catch per unit area resulting from multiple gears: Application to channel catfish and shovelnose sturgeon in the Missouri River: North American Journal of Fisheries Management, v. 28, p. 1,044-1,058.

Bajer, P.G., and Wildhaber, M.L., 2007, Population viability analysis of lower Missouri River shovelnose sturgeon with initial application to the pallid sturgeon: Journal of Applied Ichthyology, v. 23, p. 457-464.

Berry, C.R., Jr., Wildhaber, M.L., and Galat, D.L., 2004, Fish distribution and abundance-Volume 3: Population structure and habitat use of benthic fishes along the Missouri and Lower Yellowstone Rivers: U.S. Geological Survey, Cooperative Research Units, South Dakota State University, Brookings, S. Dak., 268 p., accessed November 2009 at http://infolink.cr.usgs.gov/Science/BenthicFish/Benthic Fishes_Volume_3.pdf.

Blevins, D.W., 2006, The response of suspended sediment, turbidity, and velocity to historical alterations of the Missouri River: U.S. Geological Survey Circular 1301, 8 p.

Bryan, J.L., Wildhaber, M.L., Gladish, D.W., Holan, S., and Ellerseick, M., in press, The power to detect trends in Missouri River fish populations within the Pallid Sturgeon Population Assessment Program: U.S. Geological Survey Open-File Report 2010-1020.

Criss, R.E. and Shock, E.L., 2001, Flood enhancement through flood control: Geology, v. 29, p. 875-878.

Drobish, M.R., (ed.), 2005a, Pallid sturgeon population assessment program: Yankton, S. Dak., U.S. Army Corps of Engineers, Omaha District, v., 1, 48 p.

Drobish, M.R. (ed.), 2005b, Missouri River standard operating procedures for sampling and data collection: Yankton, S. Dak., U.S. Army Corps of Engineers, Omaha District, $125 \mathrm{p}$.

Ehlmann, B.L., and Criss, R.E., 2006, Enhanced stage and stage variability on the lower Missouri River benchmarked by Lewis and Clark: Geology, v. 34, p. 977-980.

Galat, D.L., and Lipkin, R., 2000, Restoring ecological integrity of great rivers: Historical hydrographs aid in defining reference conditions for the Missouri River: Hydrobiologia, v. $422 / 423$, p. $29-48$.
Galat, D.L., Berry, C.R., Jr., Peters, E.J., and White, R.G., 2005a, Missouri River Basin; in Benke, A.C., and Cushing, C.E., eds., Rivers of North America: Boston, Mass., Elsevier/Academic Press, p. 427-480.

Galat, D.L., Berry, C.R., Jr., Gardner, W.M., Hendrickson, J.C., Mestl, G.E., Power, G.J., Stone, C., and Winston, M.R., 2005b, Spatiotemporal patterns and changes in Missouri River fishes: American Fisheries Society Symposium, v. 45 , p. $249-291$.

Hallberg, G.R., Harbaugh, J.M., and Witinok, P.M., 1979, Changes in the channel area of the Missouri River in Iowa, 1879-1976: Iowa Geological Survey Special Report Series 1, $32 \mathrm{p}$.

Hesse, L.W., 1996, Floral and faunal trends in the middle Missouri River, in Galat, D.L., and Frazier, A.G., eds., Overview of river-floodplain ecology in the Upper Mississippi River Basin; in Kelmelis, J.A., ed., Science for floodplain management into the 21 st century: Washington, D.C., U.S. Government Printing Office, v. 3, p. 73-90.

Hesse, L.W., Schmulbach, J.C., Carr, J.M., Keenlyne, K.D., Unkenholz, D.G., Robinson, J.W., and Mestl, G.E., 1989, Missouri River fishery resources in relation to past, present, and future stresses, in Dodge, D.P., ed., Proceedings of the International Large River Symposium, Canadian Special Publication of Fisheries and Aquatic Sciences 106, p. 352-371.

Hesse, L.W., and Sheets, W., 1993, The Missouri River hydrosystem: Fisheries, v. 18, p. 5-14.

Jacobson, R.B., Blevins, D.W., and Bitner, C.J., 2009, Sediment regime constraints on river restoration-An example from the lower Missouri River: The Geological Society of America Special Paper 451, p. 1-22.

Kuehl, R., 2000, Design of experiments: Statistical principles of research design and analysis ( $2 \mathrm{~d}$ ed.): Pacific Grove, Calif., Duxbury Press, 666 p.

Littell, R.C., Milliken, G.A., Stroup, W.W., Wolfinger, R.D., and Schabenberger, O., 2006, SAS for mixed models (2d ed.): Cary, N.C., SAS Institute Inc., 814 p.

Meade, R.H., ed., 1995, Contaminants in the Mississippi River, 1987-92: U.S. Geological Survey Circular 1133, 140 p., accessed Nobember 2009 at http://pubs.usgs.gov/circ/ circ1133\%.

Mestl, G.E., and Hesse, L.W., 1993, Secondary production of aquatic insects in the unchannelized Missouri River, Nebraska, in Hesse, L.W., Stalnaker, C.B., Benson, N.G. and Zuboy, J.R., eds., Restoration planning for the rivers of the Mississippi River ecosystem: Washington D.C., National Biological Survey Biological Report 19, p. 341-349, accessed November 2009 at http://oai.dtic.mil/ 
oai/oai?verb $=$ getRecord\&metadataPrefix $=$ html\&identifier $=A D A 322820$.

Milliken, G.A., and Johnson, D.E., 1984, Analysis of messy data: Belmont, Calif., Wadsworth, Inc., 473 p.

Moos, R.E., 1978, Movement and reproduction of shovelnose sturgeon, Scaphirhynchus platorynchus (Rafinesque), in the Missouri River South Dakota: Vermillion, University of South Dakota, unpublished Ph.D. dissertation, 213 p.

Murray, D., 1998, Design and analysis of group-randomized trials: New York, Oxford University Press, 467 p.

Neter, J., Kutner, M.H., Nachtsheim, C.J., and Wasserman, W., 1996, Applied linear statistical models (4th ed.): Chicago, Ill., Times Mirror Higher Education Group, Inc., 1,408 p.

Pegg, M.A., Pierce, C.L., and Roy, A., 2003, Hydrological alteration along the Missouri River Basin: A time series approach: Aquatic Sciences, v. 65, p. 1-10.

Petty, J.D., Huckings, J.N., Orazio, C.E., Lebo, J.A., Poulton, B.C., Gale, R.W., Charbonneau, C.S., and Kaiser, E.M., 1995, Determination of waterborne bioavailable organochlorine pesticide residues in the lower Missouri River: Environmental Science and Technology, v. 29, p. 2,5612,566 .

Petty, J.D., Poulton, B.C., Carbonneau, C.S., Huckins, J.N., Jones, S.B., Cameron, J.T., and Prest, H.F., 1998, Determination of bioavailable contaminants in the lower Missouri River following the flood of 1993: Environmental Science and Technology, v. 32, p. 837-842.

Pflieger, W.L., and Grace, T.B., 1987, Changes in the fish fauna of the Lower Missouri River, 1940-83, in Matthews, W.J., and Heins, D.C., eds., Community and evolutionary ecology of North Amercian stream fishes: Norman, University of Oklahoma Press, p. 166-177.

Pinter, N., 2005, One step forward, two steps back on U.S. floodplains: Science, v. 308, p. 207-208.
Pinter, N., and Heine, R., 2005, Hydrodynamic and morphodynamic response to river engineering documented by fixeddischarge analysis, lower Missouri River, USA: Journal of Hydrology, v. 302, p. 70-91.

Scheffe, H., 1959, The analysis of variance: New York, John Wiley \& Sons, Inc., 477 p.

Sims, M., Elston, D.A., Harris, M.P., and Wanless, S., 2007, Incorporating variance uncertainty into a power analysis of monitoring designs: Journal of Agricultural, Biological, and Environmental Statistics, v. 12, p. 236-249.

Sustainable Ecosystems Institute, 2005, Independent science review of the Habitat Assessment and Monitoring Program Study Plan for the Missouri River: Portland, Oreg., Sustainable Ecosystems Institute, 39 p., accessed November 2009 at http://www.sei.org/sturgeon/HAMPStudyPlanISR.pdf.

Sustainable Ecosystems Institute, 2007, Independent science review of the models and linkages for hydrological and biological processes of the Missouri River: Portland, Oreg., Sustainable Ecosystems Institute, 23 p., accessed November 2009 at http://www.sei.org/sturgeon/PASTISRFinalReport. $p d f$.

Whitmore, S.B., and Keenlyne, K.D., 1990, Rare, threatened and endangered endemic species of the Missouri River floodplain: Pierre, S. Dak., U.S. Fish and Wildlife Service, Missouri River Coordinator's Office, Report MRC-90-1.

U.S. Fish and Wildlife Service, 2000, Biological opinion on the operation of the Missouri River main stem reservoir system, operation and maintenance of the Missouri River bank stabilization and navigation project, and operation of the Kansas River reservoir system: Bismark, N. Dak., 296 p.

U.S. Fish and Wildlife Service, 2003, Amendment to the biological opinion on the operation of the Missouri River main stem reservoir system, operation and maintenance of the Missouri River bank stabilization and navigation project, and operation of the Kansas River reservoir system: Minneapolis, Minn., 308 p. 

Tables 
Table 1. Nine fish species of interest in the Habitat Assessment Monitoring Program.

$[\mathrm{mm}$, millimeters; >, greater than or equal to; --, no data]

\begin{tabular}{llc}
\hline \multicolumn{1}{c}{ Common name } & \multicolumn{1}{c}{ Scientific name } & $\begin{array}{c}\text { Mature length } \\
\text { (mm) }\end{array}$ \\
\hline Blue sucker & Cycleptus elongatus & $>500^{\text {a }}$ \\
Pallid sturgeon & Scaphirhynchus albus & $>750^{\mathrm{b}}$ \\
Plains minnow & Hybognathus placitus & -- \\
Sand shiner & Notropis stramineus & -- \\
Sauger & Sander canadensis & $>250^{\text {a }}$ \\
Shovelnose sturgeon & Scaphirhynchus platorynchus & $>550^{\mathrm{c}}$ \\
Sicklefin chub & Macrhybopsis meeki & -- \\
Speckled chub & Macrhybopsis aestivalis & -- \\
Sturgeon chub & Macrhybopsis gelida & -- \\
\hline${ }^{a}$ J. Schloesser and C.P. Paukert (Kansas State University, written commun., 2008). \\
bajer and Wildhaber (2007).
\end{tabular}

Table 2. Organization of the data collected and analyzed for a gear for each species and their maturity state in the Habitat Assessment Monitoring Program.

Universe: 2 levels, upper and lower

Radius: 2 levels, 25th and 75th quartile of bend radius

Treatment: 2 levels, untreated and treated

Bend: initially selected from each universe, radius, and treatment combination

Subsample: multiple throws of a gear evenly distributed within a bend 
Table 3. Summary of the sampling effort during 2006 using three gear types: mini-fyke net, otter trawl, and trammel net.

[These averages were calculated before data were removed due to no catch for a species.]

\begin{tabular}{|c|c|c|c|c|c|c|}
\hline Universe & Radius & Treatment & Month & $\begin{array}{l}\text { Number } \\
\text { of bends }\end{array}$ & $\begin{array}{c}\text { Average number } \\
\text { of gear types } \\
\text { per bend }\end{array}$ & $\begin{array}{c}\text { Average number } \\
\text { of subsamples } \\
\text { per gear type }\end{array}$ \\
\hline \multirow[t]{3}{*}{ Lower } & 25 & Untreated & July & 2 & 3.0 & 10.3 \\
\hline & & & Aug. & 2 & 3.0 & 5.8 \\
\hline & & & Sept. & 2 & 3.0 & 8.5 \\
\hline \multirow[t]{3}{*}{ Lower } & 25 & Treated & July & 1 & 3.0 & 6.3 \\
\hline & & & Aug. & 1 & 3.0 & 7.0 \\
\hline & & & Sept. & 1 & 3.0 & 7.7 \\
\hline \multirow[t]{3}{*}{ Lower } & 75 & Untreated & July & 2 & 3.0 & 9.8 \\
\hline & & & Aug. & 2 & 3.0 & 6.3 \\
\hline & & & Sept. & 2 & 3.0 & 8.3 \\
\hline \multirow[t]{3}{*}{ Lower } & 75 & Treated & July & 1 & 3.0 & 11.0 \\
\hline & & & Aug. & 1 & 3.0 & 8.0 \\
\hline & & & Sept. & 1 & 3.0 & 7.0 \\
\hline \multirow[t]{3}{*}{ Upper } & 25 & Untreated & July & 5 & 2.0 & 17.6 \\
\hline & & & Aug. & 5 & 2.4 & 14.5 \\
\hline & & & Sept. & 3 & 2.3 & 16.2 \\
\hline \multirow[t]{3}{*}{ Upper } & 25 & Treated & July & 3 & 2.0 & 27.0 \\
\hline & & & Aug. & 3 & 1.7 & 14.0 \\
\hline & & & Sept. & 2 & 3.0 & 18.5 \\
\hline \multirow[t]{3}{*}{ Upper } & 75 & Untreated & July & 4 & 2.3 & 19.6 \\
\hline & & & Aug. & 4 & 1.8 & 13.0 \\
\hline & & & Sept. & 3 & 3.0 & 20.4 \\
\hline \multirow[t]{3}{*}{ Upper } & 75 & Treated & July & 4 & 2.0 & 18.7 \\
\hline & & & Aug. & 4 & 2.0 & 14.2 \\
\hline & & & Sept. & 4 & 2.5 & 16.2 \\
\hline
\end{tabular}


Table 4. Summary of the bend radius analysis of covariance using shovelnose sturgeon caught in the lower Missouri River.

\begin{tabular}{|c|c|c|c|c|}
\hline \multirow{2}{*}{ Segment } & \multirow{2}{*}{ Parameter } & \multicolumn{3}{|c|}{ Gear type } \\
\hline & & Trammel net & Gill net & Otter trawl \\
\hline \multirow[t]{5}{*}{8} & Total number of observations & (a) & (b) & $39^{\mathrm{c}}$ \\
\hline & F-statistic & & & 3.062 \\
\hline & Percent variance accounted for in full model & & & 8.52 \\
\hline & Curvature parameter estimate & & & -.047 \\
\hline & Curvature P-value & & & .0895 \\
\hline \multirow[t]{5}{*}{9} & Total number of observations & $74^{d}$ & 23 & $70^{\mathrm{d}}$ \\
\hline & F-statistic & 7.16 & 5.146 & .136 \\
\hline & Percent variance accounted for in full model & 9.01 & 13.64 & .20 \\
\hline & Curvature parameter estimate & .1230 & .1180 & .0086 \\
\hline & Curvature P-value & .0093 & .0352 & .7140 \\
\hline \multirow[t]{5}{*}{10} & Total number of observations & 12 & (b) & $12^{\mathrm{c}}$ \\
\hline & F-statistic & .0072 & & .146 \\
\hline & Percent variance accounted for in full model & .08 & & 1.48 \\
\hline & Curvature parameter estimate & .0127 & & .0375 \\
\hline & Curvature P-value & .9341 & & .7102 \\
\hline \multirow[t]{5}{*}{13} & Total number of observations & 56 & 48 & 57 \\
\hline & F-statistic & .0446 & .0212 & .586 \\
\hline & Percent variance accounted for in full model & .07 & .05 & 1.06 \\
\hline & Curvature parameter estimate & -.004 & -.007 & -.007 \\
\hline & Curvature P-value & .8335 & .8848 & .4474 \\
\hline \multirow[t]{5}{*}{14} & Total number of observations & 60 & 22 & $61^{\mathrm{d}}$ \\
\hline & F-statistic & 7.207 & 5.251 & 9.93 \\
\hline & Percent variance accounted for in full model & 11.26 & 21.48 & 12.27 \\
\hline & Curvature parameter estimate & .1020 & .1580 & .0691 \\
\hline & Curvature P-value & .0096 & .0335 & .0026 \\
\hline
\end{tabular}

${ }^{a}$ No analysis was conducted due to a severe violation of statistical assumptions.

${ }^{\mathrm{b}}$ No anlaysis was conducted due to the low numbers of shovelnose sturgeon caught.

${ }^{\mathrm{c}}$ The data for this test did not meet the normality assumption, but the Shapiro-Wilk test statistic was 0.84 .

${ }^{\mathrm{d}}$ The data for this test did not meet the normality assumption, but the Shapiro-Wilk test statistic was greater than 0.9 . 
Table 5. Different groups of data that were removed from the analysis because no fish were caught for that specific factor level.

[--, the factor did not apply to the deleted group of data]

\begin{tabular}{|c|c|c|c|c|}
\hline \multirow[b]{2}{*}{ Species } & \multicolumn{4}{|c|}{ Factor level } \\
\hline & Month & Universe & Radius & Gear type \\
\hline Blue sucker-all & Aug. & -- & -- & Mini-fyke net \\
\hline Blue sucker-all & Aug. & Lower & -- & Trammel net \\
\hline Blue sucker-all & Sept. & -- & -- & Mini-fyke net \\
\hline Blue sucker-all & Sept. & Lower & -- & Otter trawl \\
\hline Blue sucker-adult & Aug. & -- & -- & Mini-fyke net \\
\hline Blue sucker-adult & Aug. & Lower & -- & Otter trawl \\
\hline Blue sucker-adult & Aug. & Lower & -- & Trammel net \\
\hline Blue sucker-adult & Sept. & -- & -- & Mini-fyke net \\
\hline Blue sucker-adult & Sept. & Lower & -- & Otter trawl \\
\hline Blue sucker-juvenile & Aug. & -- & -- & Mini-fyke net \\
\hline Blue sucker-juvenile & Aug. & -- & -- & Trammel net \\
\hline Blue sucker-juvenile & Sept. & -- & -- & Mini-fyke net \\
\hline Blue sucker-juvenile & Sept. & -- & 25 & Otter trawl \\
\hline Blue sucker-juvenile & Sept. & Lower & -- & Otter trawl \\
\hline Pallid sturgeon-all & July & -- & 25 & Trammel net \\
\hline Pallid sturgeon-all & July & Upper & -- & Trammel net \\
\hline Pallid sturgeon-all & Aug. & -- & -- & Mini-fyke net \\
\hline Pallid sturgeon-all & Aug. & -- & -- & Otter trawl \\
\hline Pallid sturgeon-all & Aug. & -- & 25 & Trammel net \\
\hline Pallid sturgeon-all & Aug. & Lower & -- & Trammel net \\
\hline Pallid sturgeon-all & Sept. & -- & -- & Mini-fyke net \\
\hline Pallid sturgeon-all & Sept. & -- & 25 & Otter trawl \\
\hline Pallid sturgeon-all & Sept. & Lower & -- & Otter trawl \\
\hline Pallid sturgeon-all & Sept. & -- & -- & Trammel net \\
\hline Pallid sturgeon-adult & July & -- & 25 & Otter trawl \\
\hline Pallid sturgeon-adult & July & Upper & -- & Otter trawl \\
\hline Pallid sturgeon-adult & July & -- & -- & Trammel net \\
\hline Pallid sturgeon-adult & Aug. & -- & -- & All gears \\
\hline Pallid sturgeon-adult & Sept. & -- & -- & All gears \\
\hline Pallid sturgeon-juvenile & July & -- & 25 & Trammel net \\
\hline Pallid sturgeon-juvenile & July & Upper & -- & Trammel net \\
\hline Pallid sturgeon-juvenile & Aug. & -- & -- & Mini-fyke net \\
\hline Pallid sturgeon-juvenile & Aug. & -- & -- & Otter trawl \\
\hline Pallid sturgeon-juvenile & Aug. & -- & 25 & Trammel net \\
\hline Pallid sturgeon-juvenile & Aug. & Lower & -- & Trammel net \\
\hline Pallid sturgeon-juvenile & Sept. & -- & -- & Mini-fyke net \\
\hline Pallid sturgeon-juvenile & Sept. & -- & 25 & Otter trawl \\
\hline Pallid sturgeon-juvenile & Sept. & Lower & -- & Otter trawl \\
\hline Pallid sturgeon-juvenile & Sept. & -- & -- & Trammel net \\
\hline Sand shiner-all & July & -- & 25 & Otter trawl \\
\hline Sand shiner-all & July & Lower & -- & Otter trawl \\
\hline Sand shiner-all & July & -- & -- & Trammel net \\
\hline Sand shiner-all & Aug. & Lower & -- & Mini-fyke net \\
\hline Sand shiner-all & Aug. & Lower & -- & Otter trawl \\
\hline Sand shiner-all & Aug. & -- & -- & Trammel net \\
\hline Sand shiner-all & Sept. & -- & 25 & Otter trawl \\
\hline Sand shiner-all & Sept. & Lower & -- & Otter trawl \\
\hline Sand shiner-all & Sept. & -- & -- & Trammel net \\
\hline
\end{tabular}


Table 5. Different groups of data that were removed from the analysis because no fish were caught for that specific factor level._-Continued

[--, the factor did not apply to the deleted group of data]

\begin{tabular}{|c|c|c|c|c|}
\hline \multirow[b]{2}{*}{ Species } & \multicolumn{4}{|c|}{ Factor level } \\
\hline & Month & Universe & Radius & Gear type \\
\hline Sauger-all & Aug. & Lower & -- & Mini-fyke net \\
\hline Sauger-all & Aug. & Lower & -- & Otter trawl \\
\hline Sauger-all & Aug. & -- & 75 & Trammel net \\
\hline Sauger-all & Aug. & Lower & -- & Trammel net \\
\hline Sauger-all & Sept. & -- & 25 & Mini-fyke net \\
\hline Sauger-all & Sept. & Lower & -- & Otter trawl \\
\hline Sauger-all & Sept. & -- & 25 & Trammel net \\
\hline Sauger-all & Sept. & Lower & -- & Trammel net \\
\hline Sauger-adult & July & -- & -- & Otter trawl \\
\hline Sauger-adult & Aug. & -- & -- & Mini-fyke net \\
\hline Sauger-adult & Aug. & Lower & -- & Otter trawl \\
\hline Sauger-adult & Aug. & -- & 75 & Trammel net \\
\hline Sauger-adult & Aug. & Lower & -- & Trammel net \\
\hline Sauger-adult & Sept. & -- & -- & Mini-fyke net \\
\hline Sauger-adult & Sept. & -- & 25 & Otter trawl \\
\hline Sauger-adult & Sept. & Lower & -- & Otter trawl \\
\hline Sauger-adult & Sept. & -- & 25 & Trammel net \\
\hline Sauger-adult & Sept. & Lower & -- & Trammel net \\
\hline Sauger-juvenile & July & -- & -- & Trammel net \\
\hline Sauger-juvenile & Aug. & Lower & -- & Mini-fyke net \\
\hline Sauger-juvenile & Aug. & -- & -- & Otter trawl \\
\hline Sauger-juvenile & Aug. & -- & -- & Trammel net \\
\hline Sauger-juvenile & Sept. & -- & 25 & Mini-fyke net \\
\hline Sauger-juvenile & Sept. & Lower & -- & Otter trawl \\
\hline Sauger-juvenile & Sept. & -- & -- & Trammel net \\
\hline Shovelnose sturgeon-all & Aug. & -- & -- & Mini-fyke net \\
\hline Shovelnose sturgeon-all & Sept. & -- & -- & Mini-fyke net \\
\hline Shovelnose sturgeon-adult & Aug. & -- & -- & Mini-fyke net \\
\hline Shovelnose sturgeon-adult & Sept. & -- & -- & Mini-fyke net \\
\hline Shovelnose sturgeon-juvenile & Aug. & -- & -- & Mini-fyke net \\
\hline Shovelnose sturgeon-juvenile & Sept. & -- & -- & Mini-fyke net \\
\hline Sicklefin chub-all & July & -- & -- & Trammel net \\
\hline Sicklefin chub-all & Aug. & -- & -- & Mini-fyke net \\
\hline Sicklefin chub-all & Aug. & -- & -- & Trammel net \\
\hline Sicklefin chub-all & Sept. & -- & -- & Mini-fyke net \\
\hline Sicklefin chub-all & Sept. & Upper & -- & Otter trawl \\
\hline Sicklefin chub-all & Sept. & -- & -- & Trammel net \\
\hline Speckled chub-all & July & -- & -- & Trammel net \\
\hline Speckled chub-all & Aug. & -- & -- & Trammel net \\
\hline Speckled chub-all & Sept. & -- & -- & Trammel net \\
\hline Sturgeon chub-all & July & -- & -- & Trammel net \\
\hline Sturgeon chub-all & Aug. & -- & -- & Mini-fyke net \\
\hline Sturgeon chub-all & Aug. & -- & -- & Trammel net \\
\hline Sturgeon chub-all & Sept. & -- & 75 & Mini-fyke net \\
\hline Sturgeon chub-all & Sept. & -- & -- & Trammel net \\
\hline
\end{tabular}


Table 6. Model statistics for all models used in the power analysis.

[--, no number was required because the unbound restricted maximum likeihood analysis was not needed]

\begin{tabular}{|c|c|c|c|c|c|c|c|c|c|c|c|c|c|}
\hline \multirow[b]{2}{*}{ Species } & \multirow[b]{2}{*}{ Month } & \multirow[b]{2}{*}{ Gear type } & \multirow[b]{2}{*}{$\begin{array}{c}\text { Yearly } \\
\text { catch per } \\
\text { unit } \\
\text { control }\end{array}$} & \multirow[b]{2}{*}{$\begin{array}{c}\text { Yearly } \\
\text { catch per } \\
\quad \text { unit } \\
\text { treatment }\end{array}$} & \multicolumn{5}{|c|}{ Factor levels } & \multicolumn{2}{|c|}{ Unbound } & \multicolumn{2}{|c|}{ Bound } \\
\hline & & & & & Universe & Treatment & Radius & Bend & $\begin{array}{c}\text { Sub- } \\
\text { samples }\end{array}$ & $\begin{array}{c}\text { Bend } \\
\text { variance } \\
\text { component } \\
\text { estimate }\end{array}$ & $\begin{array}{l}\text { Subsample } \\
\text { variance } \\
\text { component } \\
\text { estimate }\end{array}$ & $\begin{array}{c}\text { Bend } \\
\text { variance } \\
\text { component } \\
\text { estimate }\end{array}$ & $\begin{array}{c}\text { Subsample } \\
\text { variance } \\
\text { component } \\
\text { estimate }\end{array}$ \\
\hline Blue sucker-all & July & Otter trawl & 0.1362 & 0.1339 & 2 & 2 & 2 & 21 & 167 & -- & -- & 0.0116 & 0.2438 \\
\hline Blue sucker-all & July & Trammel net & .4852 & .2957 & 2 & 2 & 2 & 22 & 200 & -- & -- & .4512 & 1.8540 \\
\hline Blue sucker-all & Aug. & Otter trawl & .0491 & .0396 & 2 & 2 & 2 & 17 & 108 & -0.0023 & 0.0466 & 0 & .0452 \\
\hline Blue sucker-all & Aug. & Trammel net & .1392 & .0642 & 1 & 2 & 2 & 9 & 73 & -.0006 & .1116 & 0 & .1113 \\
\hline Blue sucker-all & Sept. & Otter trawl & .0922 & .1088 & 1 & 2 & 2 & 9 & 97 & -- & -- & .0019 & .0841 \\
\hline Blue sucker-all & Sept. & Trammel net & .2487 & .0639 & 2 & 2 & 2 & 17 & 128 & -- & -- & .0326 & .2877 \\
\hline Blue sucker-adult & July & Otter trawl & .1194 & .1112 & 2 & 2 & 2 & 21 & 167 & -- & -- & .0139 & .2315 \\
\hline Blue sucker-adult & July & Trammel net & .4637 & .2791 & 2 & 2 & 2 & 22 & 200 & -- & -- & .4547 & 1.7684 \\
\hline Blue sucker-adult & Aug. & Otter trawl & .0447 & .0792 & 1 & 2 & 2 & 11 & 88 & -.0019 & .0415 & 0 & .0402 \\
\hline Blue sucker-adult & Aug. & Trammel net & .1392 & .0642 & 1 & 2 & 2 & 9 & 73 & -.0006 & .1116 & 0 & .1113 \\
\hline Blue sucker-adult & Sept. & Otter trawl & .0922 & .0989 & 1 & 2 & 2 & 9 & 97 & -- & -- & .0017 & .0811 \\
\hline Blue sucker-adult & Sept. & Trammel net & .1369 & .0639 & 2 & 2 & 2 & 17 & 128 & -- & -- & .0175 & .2380 \\
\hline Blue sucker-juvenile & July & Otter trawl & .0168 & .0228 & 2 & 2 & 2 & 21 & 167 & -- & -- & .0003 & .0107 \\
\hline Blue sucker-juvenile & July & Trammel net & .0215 & .0167 & 2 & 2 & 2 & 22 & 200 & -.0003 & .0206 & 0 & .0204 \\
\hline Blue sucker-juvenile & Aug. & Otter trawl & .0267 & 0 & 2 & 2 & 2 & 17 & 108 & -- & -- & 0.0001 & .0120 \\
\hline Blue sucker-juvenile & Sept. & Otter trawl & 0 & .0197 & 1 & 2 & 1 & 5 & 57 & -.0004 & .0072 & 0 & .0069 \\
\hline Blue sucker-juvenile & Sept. & Trammel net & .1118 & 0 & 2 & 2 & 2 & 17 & 128 & -- & -- & .0085 & .0505 \\
\hline Pallid sturgeon-all & July & Otter trawl & .0074 & .0375 & 2 & 2 & 2 & 21 & 167 & -.0003 & .0042 & 0 & .0040 \\
\hline Pallid sturgeon-all & July & Trammel net & .0335 & 0 & 1 & 2 & 1 & 3 & 12 & -- & -- & .0007 & .0060 \\
\hline Pallid sturgeon-all & Aug. & Trammel net & 0 & .0230 & 1 & 2 & 1 & 5 & 41 & -- & -- & $1.5 \times 10^{-5}$ & .0095 \\
\hline Pallid sturgeon-all & Sept. & Otter trawl & .0210 & 0 & 1 & 2 & 1 & 5 & 57 & -- & -- & 0.0003 & .0055 \\
\hline Pallid sturgeon-adult & July & Otter trawl & 0 & .1191 & 1 & 2 & 1 & 3 & 12 & -.0047 & .0189 & 0 & .0170 \\
\hline Pallid sturgeon-juvenile & July & Otter trawl & .0074 & .0077 & 2 & 2 & 2 & 21 & 167 & -.0002 & .0031 & 0 & .0030 \\
\hline Pallid sturgeon-juvenile & July & Trammel net & .0335 & 0 & 1 & 2 & 1 & 3 & 12 & -- & -- & .0007 & .0060 \\
\hline Pallid sturgeon-juvenile & Aug. & Trammel net & 0 & .0230 & 1 & 2 & 1 & 5 & 41 & -- & -- & $1.5 \times 10^{-5}$ & .0095 \\
\hline Pallid sturgeon-juvenile & Sept. & Otter trawl & .0210 & 0 & 1 & 2 & 1 & 5 & 57 & -- & -- & .0003 & .0055 \\
\hline Sand shiner-all & July & Otter trawl & .5821 & 0 & 1 & 2 & 1 & 7 & 72 & -- & -- & .1633 & 4.2613 \\
\hline Sand shiner-all & Aug. & Mini-fyke net & 14.1230 & 8.0063 & 1 & 2 & 2 & 12 & 92 & -- & -- & 61.6298 & 672.7232 \\
\hline Sand shiner-all & Aug. & Otter trawl & .0271 & .0433 & 1 & 2 & 2 & 11 & 88 & -.0004 & .0197 & 0 & .0195 \\
\hline Sand shiner-all & Sept. & Mini-fyke net & 1.7195 & 2.9493 & 1 & 2 & 2 & 12 & 106 & -- & -- & 2.0604 & 25.4333 \\
\hline Sand shiner-all & Sept. & Otter trawl & .0392 & 0 & 1 & 2 & 1 & 5 & 57 & -.0010 & .0155 & 0 & .0147 \\
\hline Sauger-all & July & Otter trawl & .0294 & .0183 & 2 & 2 & 2 & 21 & 167 & -- & -- & .0008 & .0205 \\
\hline Sauger-all & July & Trammel net & .0180 & .0180 & 2 & 2 & 2 & 22 & 200 & -.0001 & .0097 & 0 & .0096 \\
\hline
\end{tabular}


Table 6. Model statistics for all models used in the power analysis. - Continued

[--, no number was required because the unbound restricted maximum likeihood analysis was not needed]

\begin{tabular}{|c|c|c|c|c|c|c|c|c|c|c|c|c|c|}
\hline \multirow[b]{2}{*}{ Species } & \multirow[b]{2}{*}{ Month } & \multirow[b]{2}{*}{ Gear type } & \multirow[b]{2}{*}{$\begin{array}{c}\text { Yearly } \\
\text { catch per } \\
\text { unit } \\
\text { control }\end{array}$} & \multirow[b]{2}{*}{$\begin{array}{c}\text { Yearly } \\
\text { catch per } \\
\text { unit } \\
\text { treatment }\end{array}$} & \multicolumn{5}{|c|}{ Factor levels } & \multicolumn{2}{|c|}{ Unbound } & \multicolumn{2}{|c|}{ Bound } \\
\hline & & & & & Universe & Treatment & Radius & Bend & $\begin{array}{c}\text { Sub- } \\
\text { samples }\end{array}$ & $\begin{array}{c}\text { Bend } \\
\text { variance } \\
\text { component } \\
\text { estimate }\end{array}$ & $\begin{array}{l}\text { Subsample } \\
\text { variance } \\
\text { component } \\
\text { estimate }\end{array}$ & $\begin{array}{c}\text { Bend } \\
\text { variance } \\
\text { component } \\
\text { estimate }\end{array}$ & $\begin{array}{c}\text { Subsample } \\
\text { variance } \\
\text { component } \\
\text { estimate }\end{array}$ \\
\hline Sauger-all & Aug. & Mini-fyke net & 0.0101 & 0.0346 & 1 & 2 & 2 & 12 & 92 & -0.0012 & 0.0093 & 0 & 0.0078 \\
\hline Sauger-all & Aug. & Otter trawl & .0113 & .0162 & 1 & 2 & 2 & 11 & 88 & -- & -- & .0003 & .0161 \\
\hline Sauger-all & Aug. & Trammel net & .0298 & 0 & 1 & 2 & 1 & 4 & 32 & -- & -- & .0007 & .0159 \\
\hline Sauger-all & Sept. & Mini-fyke net & 0 & .0174 & 1 & 2 & 1 & 7 & 61 & -- & -- & .0001 & .0050 \\
\hline Sauger-all & Sept. & Otter trawl & .0324 & .0139 & 1 & 2 & 2 & 9 & 97 & -.0004 & .0165 & 0 & .0163 \\
\hline Sauger-all & Sept. & Trammel net & 0 & .0473 & 1 & 2 & 1 & 7 & 64 & -.0007 & .0189 & 0 & .0184 \\
\hline Sauger-adult & July & Trammel net & .0180 & .0180 & 2 & 2 & 2 & 22 & 200 & -.0001 & .0096 & 0 & .0096 \\
\hline Sauger-adult & Aug. & Otter trawl & .0113 & .0162 & 1 & 2 & 2 & 11 & 88 & -- & -- & .0003 & .0161 \\
\hline Sauger-adult & Aug. & Trammel net & .0298 & 0 & 1 & 2 & 1 & 4 & 32 & -- & -- & .0007 & .0159 \\
\hline Sauger-adult & Sept. & Otter trawl & .0186 & 0 & 1 & 2 & 1 & 5 & 57 & -- & -- & .0002 & .0043 \\
\hline Sauger-adult & Sept. & Trammel net & 0 & .0473 & 1 & 2 & 1 & 7 & 64 & -.0007 & .0189 & 0 & .0184 \\
\hline Sauger-juvenile & July & Otter trawl & .0294 & .0183 & 2 & 2 & 2 & 21 & 167 & -- & -- & .0008 & .0205 \\
\hline Sauger-juvenile & Aug. & Mini-fyke net & .0101 & .0346 & 1 & 2 & 2 & 12 & 92 & -.0012 & .0093 & 0 & .0078 \\
\hline Sauger-juvenile & Sept. & Mini-fyke net & 0 & .0174 & 1 & 2 & 1 & 7 & 61 & -- & -- & .0001 & .0050 \\
\hline Sauger-juvenile & Sept. & Otter trawl & .0231 & .0139 & 1 & 2 & 2 & 9 & 97 & -.0006 & .0140 & 0 & .0136 \\
\hline Shovelnose sturgeon-all & July & Otter trawl & .2938 & .1844 & 2 & 2 & 2 & 21 & 167 & -.0104 & .1892 & 0 & .1826 \\
\hline Shovelnose sturgeon-all & July & Trammel net & .6384 & .8190 & 2 & 2 & 2 & 22 & 200 & -- & -- & .4136 & 5.4674 \\
\hline Shovelnose sturgeon-all & Aug. & Otter trawl & .3463 & .3465 & 2 & 2 & 2 & 17 & 108 & -.0700 & .8265 & 0 & .7773 \\
\hline Shovelnose sturgeon-all & Aug. & Trammel net & .1289 & .1830 & 2 & 2 & 2 & 15 & 97 & -.0185 & .4583 & 0 & .4485 \\
\hline Shovelnose sturgeon-all & Sept. & Otter trawl & .6319 & .4555 & 2 & 2 & 2 & 15 & 119 & -- & -- & .1030 & 2.3216 \\
\hline Shovelnose sturgeon-all & Sept. & Trammel net & .9034 & .3588 & 2 & 2 & 2 & 17 & 128 & -.0982 & 1.5715 & 0 & 1.5057 \\
\hline Shovelnose sturgeon-adult & July & Otter trawl & .0845 & .1234 & 2 & 2 & 2 & 21 & 167 & -.0011 & .0459 & 0 & .0452 \\
\hline Shovelnose sturgeon-adult & July & Trammel net & .4494 & .2461 & 2 & 2 & 2 & 22 & 200 & -- & -- & .0373 & .9577 \\
\hline Shovelnose sturgeon-adult & Aug. & Otter trawl & .2242 & .1524 & 2 & 2 & 2 & 17 & 108 & -.0019 & .3076 & 0 & .3064 \\
\hline Shovelnose sturgeon-adult & Aug. & Trammel net & .0234 & .1288 & 2 & 2 & 2 & 15 & 97 & -.0061 & .0625 & 0 & .0593 \\
\hline Shovelnose sturgeon-adult & Sept. & Otter trawl & .1764 & .0784 & 2 & 2 & 2 & 15 & 119 & -.0071 & .3231 & 0 & .3194 \\
\hline Shovelnose sturgeon-adult & Sept. & Trammel net & .3586 & .1471 & 2 & 2 & 2 & 17 & 128 & -.0170 & .2724 & 0 & .2598 \\
\hline Shovelnose sturgeon-juvenile & July & Otter trawl & .2092 & .0610 & 2 & 2 & 2 & 21 & 167 & -.0084 & .1183 & 0 & .1126 \\
\hline Shovelnose sturgeon-juvenile & July & Trammel net & .1890 & .5729 & 2 & 2 & 2 & 22 & 200 & -- & -- & .1724 & 2.2975 \\
\hline Shovelnose sturgeon-juvenile & Aug. & Otter trawl & .1222 & .1940 & 2 & 2 & 2 & 17 & 108 & -.0221 & .2387 & 0 & .2247 \\
\hline Shovelnose sturgeon-juvenile & Aug. & Trammel net & .1055 & .0542 & 2 & 2 & 2 & 15 & 97 & -.0068 & .3777 & 0 & .3740 \\
\hline Shovelnose sturgeon-juvenile & Sept. & Otter trawl & .4555 & .3771 & 2 & 2 & 2 & 15 & 119 & -- & -- & .0823 & 1.2848 \\
\hline Shovelnose sturgeon-juvenile & Sept. & Trammel net & .5448 & .2117 & 2 & 2 & 2 & 17 & 128 & -.0371 & .5933 & 0 & .5697 \\
\hline
\end{tabular}


Table 6. Model statistics for all models used in the power analysis.—Continued

[--, no number was required because the unbound restricted maximum likeihood analysis was not needed]

\begin{tabular}{|c|c|c|c|c|c|c|c|c|c|c|c|c|c|}
\hline \multirow[b]{2}{*}{ Species } & \multirow[b]{2}{*}{ Month } & \multirow[b]{2}{*}{ Gear type } & \multirow[b]{2}{*}{$\begin{array}{c}\text { Yearly } \\
\text { catch per } \\
\text { unit } \\
\text { control }\end{array}$} & \multirow[b]{2}{*}{$\begin{array}{c}\text { Yearly } \\
\text { catch per } \\
\text { unit } \\
\text { treatment }\end{array}$} & \multicolumn{5}{|c|}{ Factor levels } & \multicolumn{2}{|c|}{ Unbound } & \multicolumn{2}{|c|}{ Bound } \\
\hline & & & & & Universe & Treatment & Radius & Bend & $\begin{array}{c}\text { Sub- } \\
\text { samples }\end{array}$ & $\begin{array}{c}\text { Bend } \\
\text { variance } \\
\text { component } \\
\text { estimate }\end{array}$ & $\begin{array}{l}\text { Subsample } \\
\text { variance } \\
\text { component } \\
\text { estimate }\end{array}$ & $\begin{array}{c}\text { Bend } \\
\text { variance } \\
\text { component } \\
\text { estimate }\end{array}$ & $\begin{array}{c}\text { Subsample } \\
\text { variance } \\
\text { component } \\
\text { estimate }\end{array}$ \\
\hline Sicklefin chub-all & July & Otter trawl & 2.1561 & 1.3784 & 2 & 2 & 2 & 21 & 167 & -0.9304 & 14.8871 & 0 & 14.1697 \\
\hline Sicklefin chub-all & Aug. & Otter trawl & .3079 & .4942 & 2 & 2 & 2 & 17 & 108 & -.0634 & .5223 & 0 & .4641 \\
\hline Sicklefin chub-all & Sept. & Otter trawl & .0494 & 0 & 1 & 2 & 2 & 6 & 22 & -- & -- & .0015 & .0157 \\
\hline Speckled chub-all & July & Otter trawl & .1745 & .2799 & 2 & 2 & 2 & 21 & 167 & -.0033 & .1411 & 0 & .1389 \\
\hline Speckled chub-all & Aug. & Mini-fyke net & .0811 & 0 & 1 & 2 & 2 & 12 & 92 & -- & -- & .0031 & .0492 \\
\hline Speckled chub-all & Aug. & Otter trawl & .3623 & .2317 & 2 & 2 & 2 & 17 & 108 & -- & -- & .0179 & .9556 \\
\hline Speckled chub-all & Sept. & Mini-fyke net & .0897 & .1176 & 1 & 2 & 2 & 12 & 106 & -- & -- & .0011 & .1023 \\
\hline Speckled chub-all & Sept. & Otter trawl & .3614 & .7738 & 2 & 2 & 2 & 15 & 119 & -- & -- & 1.2098 & 11.3698 \\
\hline Sturgeon chub-all & July & Otter trawl & .0317 & .0332 & 2 & 2 & 2 & 21 & 167 & -.0004 & .0205 & 0 & .0202 \\
\hline Sturgeon chub-all & Aug. & Otter trawl & .1357 & .1155 & 2 & 2 & 2 & 17 & 108 & -- & -- & .0017 & .3960 \\
\hline Sturgeon chub-all & Sept. & Mini-fyke net & .0223 & .1081 & 1 & 2 & 1 & 5 & 45 & -- & -- & .0038 & .0384 \\
\hline Sturgeon chub-all & Sept. & Otter trawl & .0876 & .0849 & 2 & 2 & 2 & 15 & 119 & -- & -- & .0087 & .1444 \\
\hline
\end{tabular}


Table 7. The total count of fish (proportion of non-occurrence in subsamples) and the number of bends the species occupied (proportion of non-occurrence in bends) in the power analysis for each gear type in July 2006.

[--, species was not caught for that gear]

\begin{tabular}{|c|c|c|c|c|c|c|c|c|c|c|c|}
\hline \multirow{3}{*}{$\frac{\text { Species }}{\text { Blue sucker-all }}$} & \multicolumn{4}{|c|}{ Mini-fyke net } & \multicolumn{4}{|c|}{ Otter trawl } & \multicolumn{3}{|c|}{ Trammel net } \\
\hline & \multicolumn{2}{|c|}{ Count } & \multicolumn{2}{|c|}{ Bend } & \multicolumn{2}{|c|}{ Count } & \multicolumn{2}{|c|}{ Bend } & \multicolumn{2}{|c|}{ Count } & Bend \\
\hline & -- & -- & -- & -- & & $(0.83)$ & & $(0.19)$ & 156 & $(0.74)$ & $18(0.18)$ \\
\hline Blue sucker-adult & -- & -- & -- & -- & 41 & $(.86)$ & 14 & $(.33)$ & 150 & $(.75)$ & $17 \quad(.23)$ \\
\hline Blue sucker-juvenile & -- & -- & -- & -- & 5 & $(.97)$ & 5 & $(.76)$ & 6 & $(.97)$ & $6 \quad(.73)$ \\
\hline Palid sturgeon & -- & -- & -- & -- & 4 & $(.98)$ & 4 & $(.81)$ & 1 & $(.92)$ & $1 \quad(.67)$ \\
\hline Pallid sturgeon-adult & -- & -- & -- & -- & 1 & $(.92)$ & 1 & $(.67)$ & -- & -- & -- \\
\hline Pallid sturgeon-juvenile & -- & -- & -- & -- & 3 & $(.98)$ & 3 & $(.86)$ & 1 & $(.92)$ & $1 \quad(.67)$ \\
\hline Sand shiner-all & 297 & $(0.59)$ & 4 & $(0.2)$ & 19 & $(.97)$ & 2 & $(.71)$ & -- & -- & -- \\
\hline Sauger-all & -- & -- & -- & -- & 5 & $(.97)$ & 5 & $(.76)$ & 5 & $(.98)$ & $5 \quad(.77)$ \\
\hline Sauger-adult & -- & -- & -- & -- & -- & -- & -- & -- & 5 & $(.98)$ & $5 \quad(.77)$ \\
\hline Sauger-juvenile & -- & -- & -- & -- & 5 & $(.97)$ & 5 & $(.76)$ & -- & -- & -- \\
\hline Shovelnose sturgeon-all & -- & -- & -- & -- & 62 & $(.77)$ & 20 & $(.05)$ & 204 & $(.69)$ & $20 \quad(.09)$ \\
\hline Shovelnose sturgeon-adult & -- & -- & -- & -- & 22 & $(.89)$ & 14 & $(.33)$ & 96 & $(.8)$ & $18 \quad(.18)$ \\
\hline Shovelnose sturgeon-juvenile & -- & -- & -- & -- & 40 & $(.84)$ & 17 & $(.19)$ & 108 & $(.79)$ & $17 \quad(.23)$ \\
\hline Sicklefin chub-all & -- & -- & -- & -- & 173 & $(.91)$ & 9 & $(.57)$ & -- & -- & -- \\
\hline Speckled chub-all & 4 & $(.93)$ & 2 & $(.6)$ & 42 & $(.89)$ & 14 & $(.33)$ & -- & -- & -- \\
\hline Sturgeon chub-all & -- & -- & -- & -- & 9 & $(.95)$ & 8 & $(.62)$ & -- & -- & -- \\
\hline
\end{tabular}

Table 8. The total count of fish (proportion of non-occurrence in subsamples) and the number of bends the species occupied (proportion of non-occurrence in bends) in the power analysis for each gear type in August 2006.

[--, species was not caught for that gear]

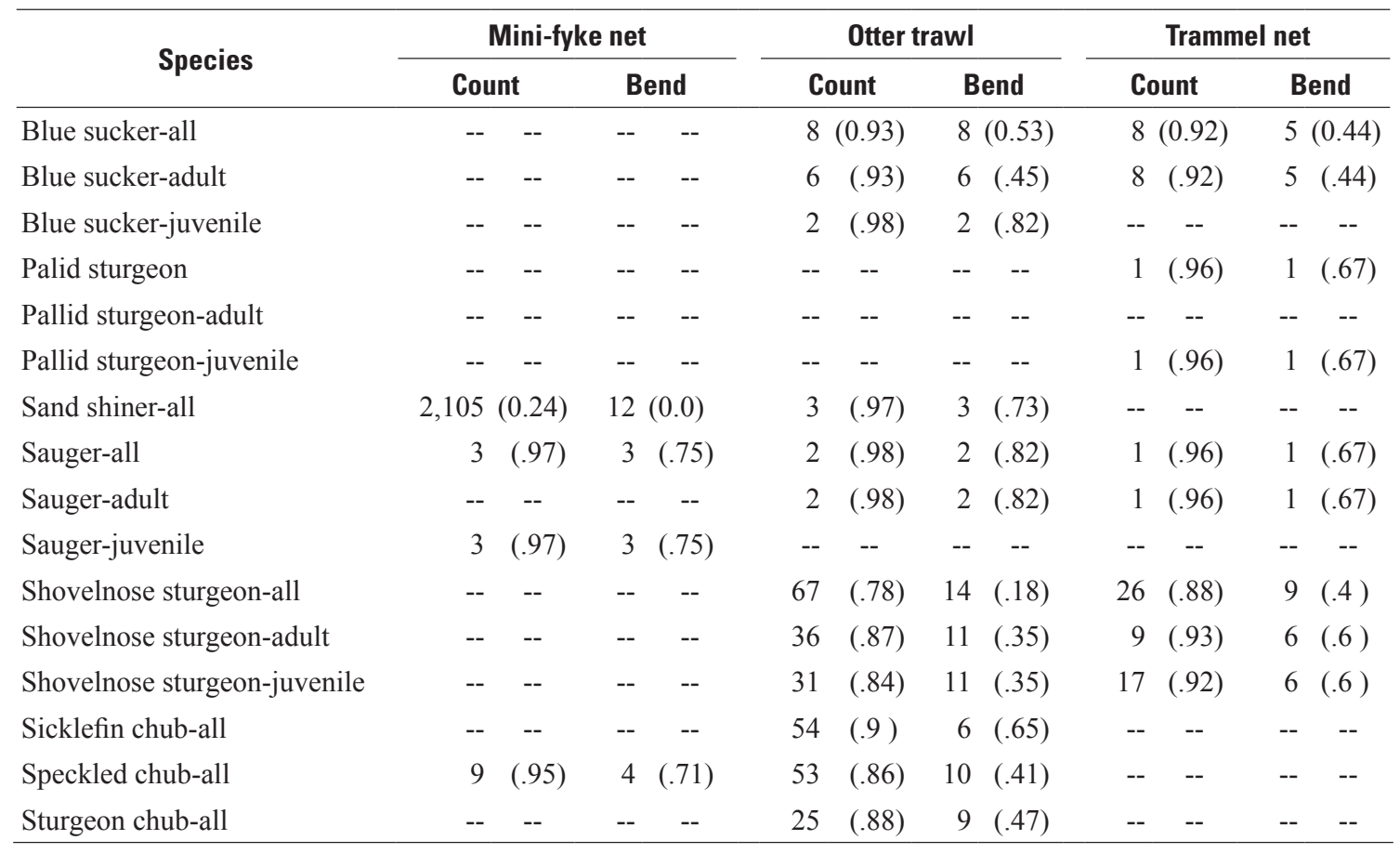


Table 9. The total count of fish (proportion of non-occurrence in subsamples) and the number of bends the species occupied (proportion of non-occurrence in bends) in the power analysis for each gear type in September 2006.

[--, species was not caught for that gear]

\begin{tabular}{|c|c|c|c|c|c|c|}
\hline \multirow{2}{*}{ Species } & \multicolumn{2}{|c|}{ Mini-fyke net } & \multicolumn{2}{|c|}{ Otter trawl } & \multicolumn{2}{|c|}{ Trammel net } \\
\hline & Count & Bend & Count & Bend & Count & Bend \\
\hline Blue sucker-all & -- $\quad--$ & -- $\quad--$ & $18(0.84)$ & $7(0.22)$ & $41(0.83)$ & $9(0.47)$ \\
\hline Blue sucker-adult & $--\quad--$ & -- $\quad--$ & $17(.85)$ & $7 \quad(.22)$ & $29(.84)$ & $9 \quad(.47)$ \\
\hline Blue sucker-juvenile & $--\quad--$ & $--\quad--$ & $1 \quad(.98)$ & $1 \quad(.8)$ & $12(.97)$ & $3(.82)$ \\
\hline Palid sturgeon & $--\quad--$ & $--\quad--$ & $1 \quad(.98)$ & $1 \quad(.8)$ & $--\quad--$ & $--\quad--$ \\
\hline Pallid sturgeon-adult & -- $\quad--$ & $--\quad--$ & -- $\quad--$ & $--\quad--$ & -- & $--\quad--$ \\
\hline Pallid sturgeon-juvenile & $--\quad--$ & -- $\quad--$ & $1 \quad(.98)$ & $1(.8)$ & $--\quad--$ & -- $\quad--$ \\
\hline Sand shiner-all & $479(0.4)$ & $12(0.0)$ & $2(.96)$ & $2(.6)$ & $--\quad--$ & -- $\quad--$ \\
\hline Sauger-all & $1(.98)$ & $1 \quad(.86)$ & $3(.97)$ & $3(.67)$ & $2(.97)$ & $2(.71)$ \\
\hline Sauger-adult & $--\quad--$ & $--\quad--$ & $1 \quad(.98)$ & $1(.8)$ & $2(.97)$ & $2(.71)$ \\
\hline Sauger-juvenile & $1(.98)$ & $1 \quad(.86)$ & $2(.98)$ & $2(.78)$ & $--\quad--$ & -- $\quad--$ \\
\hline Shovelnose sturgeon-all & $--\quad--$ & -- $\quad--$ & $146 \quad(.61)$ & $13(.13)$ & $101 \quad(.88)$ & $8 \quad(.53)$ \\
\hline Shovelnose sturgeon-adult & $--\quad--$ & $--\quad--$ & $35(.83)$ & $10(.33)$ & $42 \quad(.92)$ & $6(.65)$ \\
\hline Shovelnose sturgeon-juvenile & $--\quad--$ & $--\quad--$ & 111 & $12(.2)$ & $59 \quad(.9)$ & $8(.53)$ \\
\hline Sicklefin chub-all & $--\quad--$ & $--\quad--$ & $3(.91)$ & $2(.67)$ & -- & $--\quad--$ \\
\hline Speckled chub-all & $18(.89)$ & $9 \quad(.25)$ & $123(.73)$ & $11 \quad(.27)$ & -- $\quad--$ & -- $\quad--$ \\
\hline Sturgeon chub-all & $4 \quad(.94)$ & $2(.6)$ & $26(.88)$ & $8 \quad(.47)$ & $--\quad--$ & -- $\quad--$ \\
\hline
\end{tabular}


Table 10. Summary of the different bend/subsample levels needed to reach a power of 0.8 when detecting treatment differences in the Habitat Assessment

Monitoring Program.

[--, species did not meet minimum catch criteria and power was not calculated; >, greater than]

\begin{tabular}{|c|c|c|c|c|c|c|c|c|}
\hline \multirow{2}{*}{ Species } & \multicolumn{2}{|c|}{$\begin{array}{c}\text { Bend/subsample level for mini- } \\
\text { fyke net }\end{array}$} & \multicolumn{3}{|c|}{ Bend/subsample level for otter trawl } & \multicolumn{3}{|c|}{ Bend/subsample level for trammel net } \\
\hline & August & September & July & August & September & July & August & September \\
\hline Blue sucker-all & -- & -- & $>80 / 16$ & $>80 / 16^{a}$ & $>80 / 16$ & $>80 / 16$ & $20 / 16^{a}$ & $40 / 8$ \\
\hline Blue sucker-adult & -- & -- & $>80 / 16$ & $40 / 16^{\mathrm{a}}$ & $>80 / 16$ & $>80 / 16$ & $20 / 16^{\text {a }}$ & $>80 / 16$ \\
\hline Blue sucker-juvenile & -- & -- & $>80 / 16$ & $20 / 16^{b}$ & $20 / 16^{\text {ac }}$ & $>80 / 16^{\mathrm{a}}$ & -- & $20 / 8^{b}$ \\
\hline Pallid sturgeon-all & -- & -- & $20 / 4^{\text {a }}$ & -- & $40 / 8^{b}$ & $20 / 12 b$ & $20 / 16^{c}$ & -- \\
\hline Pallid sturgeon-juvenile & -- & -- & $>80 / 16^{\mathrm{a}}$ & -- & $40 / 8^{b}$ & $20 / 12^{b}$ & $20 / 16^{c}$ & -- \\
\hline Sand shiner-all & $80 / 8$ & $40 / 16$ & $40 / 8^{b}$ & $80 / 16^{a}$ & $20 / 8^{a b}$ & -- & -- & -- \\
\hline Sauger-all & $20 / 12^{\text {a }}$ & $40 / 12^{c}$ & $>80 / 16$ & $>80 / 16$ & $80 / 12^{\text {a }}$ & $>80 / 16^{\mathrm{a}}$ & $40 / 12^{b}$ & $20 / 8$ a c \\
\hline Sauger-adult & -- & -- & -- & $>80 / 16$ & $40 / 8^{b}$ & $>80 / 16^{\mathrm{a}}$ & $40 / 12^{b}$ & $20 / 8$ a c \\
\hline Sauger-juvenile & $20 / 12^{a}$ & $40 / 12^{c}$ & $>80 / 16$ & -- & $>80 / 16^{\mathrm{a}}$ & -- & -- & -- \\
\hline Shovelnose sturgeon-all & -- & -- & $20 / 16^{\mathrm{a}}$ & $>80 / 16^{a}$ & $>80 / 16$ & $>80 / 16$ & $>80 / 16^{\mathrm{a}}$ & $20 / 8^{\text {a }}$ \\
\hline Shovelnose sturgeon-juvenile & -- & -- & $20 / 8^{\text {a }}$ & $80 / 12^{\text {a }}$ & $>80 / 16$ & $40 / 12$ & $>80 / 16^{\mathrm{a}}$ & $20 / 8^{\text {a }}$ \\
\hline Sicklefin chub-all & -- & -- & $40 / 12^{a}$ & $20 / 12^{\text {a }}$ & $20 / 12^{b}$ & -- & -- & -- \\
\hline Speckled chub-all & $20 / 12^{b}$ & $>80 / 16$ & $20 / 12^{\text {a }}$ & $80 / 16$ & $>80 / 16$ & -- & -- & -- \\
\hline Sturgeon chub-all & -- & $20 / 8$ & $>80 / 16^{\mathrm{a}}$ & $>80 / 16$ & $>80 / 16$ & -- & -- & -- \\
\hline
\end{tabular}

${ }^{a}$ Models with an initial negative bend variance component estimate and re-estimated using standard Restricted Maxiumum Likelihood estimation methods.

${ }^{\mathrm{b}}$ Models with the treatment mean response of zero.

${ }^{\mathrm{c}}$ Models with the control mean response of zero. 
Table 11. Summary of blue sucker-all power, required mean difference, and multiplier needed using current treatment mean difference at different bend/subsample levels for each gear type and month of the Habitat Assessment Monitoring Program.

[power $=0.8, \alpha=0.05]$

\begin{tabular}{|c|c|c|c|c|c|c|c|c|c|c|c|c|c|c|c|c|c|c|c|}
\hline \multirow{3}{*}{ Parameter } & \multirow{3}{*}{ Gear type } & \multirow{3}{*}{ Month } & \multirow{3}{*}{$\begin{array}{c}\text { Current } \\
\text { model } \\
\text { treatment } \\
\text { difference }\end{array}$} & \multicolumn{16}{|c|}{ Bend/subsample level } \\
\hline & & & & \multicolumn{4}{|c|}{4} & \multicolumn{4}{|c|}{20} & \multicolumn{4}{|c|}{40} & \multicolumn{4}{|c|}{80} \\
\hline & & & & 4 & 8 & 12 & 16 & 4 & 8 & 12 & 16 & 4 & 8 & 12 & 16 & 4 & 8 & 12 & 16 \\
\hline \multirow[t]{6}{*}{ Power } & Otter trawl & July & 0.00224 & 0.05 & 0.05 & 0.05 & 0.05 & 0.05 & 0.05 & 0.05 & 0.05 & 0.05 & 0.05 & 0.05 & 0.05 & 0.05 & 0.05 & 0.05 & 0.05 \\
\hline & & Aug. ${ }^{a}$ & .00950 & .05 & .05 & .06 & .06 & .06 & .07 & .08 & .09 & .07 & .09 & .11 & .13 & .09 & .13 & .16 & .20 \\
\hline & & Sept. & .01654 & .05 & .05 & .06 & .06 & .06 & .07 & .09 & .09 & .08 & .10 & .12 & .14 & .11 & .15 & .20 & .23 \\
\hline & Trammel net & July & .18947 & .06 & .06 & .06 & .06 & .10 & .11 & .12 & .12 & .14 & .18 & .19 & .20 & .24 & .30 & .34 & .36 \\
\hline & & Aug. ${ }^{a}$ & .07500 & .09 & .13 & .17 & .22 & .29 & .51 & .68 & .80 & .52 & .81 & .93 & .98 & .81 & .98 & 1.00 & 1.00 \\
\hline & & Sept. & .18485 & .12 & .16 & .18 & .20 & .44 & .60 & .69 & .73 & .72 & .88 & .93 & .96 & .95 & .99 & 1.00 & 1.00 \\
\hline \multirow{6}{*}{$\begin{array}{l}\text { Difference } \\
\text { needed for } \\
\text { power to } \\
\text { equal } 0.8\end{array}$} & Otter trawl & July & .00224 & .56 & .42 & .37 & .34 & .24 & .18 & .16 & .15 & .17 & .13 & .11 & .10 & .12 & .09 & .08 & .07 \\
\hline & & Aug. ${ }^{a}$ & .00950 & .22 & .16 & .13 & .11 & .09 & .07 & .05 & .05 & .07 & .05 & .04 & .03 & .05 & .03 & .03 & .02 \\
\hline & & Sept. & .01654 & .33 & .24 & .20 & .18 & .14 & .10 & .08 & .08 & .10 & .07 & .06 & .05 & .07 & .05 & .04 & .04 \\
\hline & Trammel net & July & .18947 & 1.97 & 1.71 & 1.61 & 1.55 & .85 & .74 & .69 & .67 & .60 & .52 & .49 & .47 & .42 & .37 & .35 & .33 \\
\hline & & Aug. ${ }^{a}$ & .07500 & .36 & .25 & .21 & .18 & .15 & .11 & .09 & .07 & .11 & .07 & .06 & .05 & .07 & .05 & .04 & .04 \\
\hline & & Sept. & .18485 & .67 & .54 & .49 & .46 & .29 & .23 & .21 & .20 & .20 & .16 & .15 & .14 & .14 & .12 & .11 & .10 \\
\hline \multirow{6}{*}{$\begin{array}{l}\text { Multiplier } \\
\text { needed for } \\
\text { power to } \\
\text { equal } 0.8\end{array}$} & Otter trawl & July & .00224 & 248.42 & 189.21 & 164.82 & 151.15 & 107.27 & 81.70 & 71.17 & 65.27 & 75.60 & 57.58 & 50.16 & 46.00 & 53.37 & 40.65 & 35.41 & 32.48 \\
\hline & & Aug. ${ }^{\mathrm{a}}$ & .00950 & 23.11 & 16.34 & 13.34 & 11.55 & 9.98 & 7.06 & 5.76 & 4.99 & 7.03 & 4.97 & 4.06 & 3.52 & 4.96 & 3.51 & 2.87 & 2.48 \\
\hline & & Sept. & .01654 & 19.75 & 14.53 & 12.31 & 11.03 & 8.21 & 6.04 & 5.12 & 4.58 & 5.77 & 4.24 & 3.59 & 3.22 & 4.07 & 2.99 & 2.53 & 2.27 \\
\hline & Trammel net & July & .18947 & 10.42 & 9.01 & 8.48 & 8.21 & 4.50 & 3.89 & 3.66 & 3.54 & 3.17 & 2.74 & 2.58 & 2.50 & 2.24 & 1.94 & 1.82 & 1.76 \\
\hline & & Aug. ${ }^{\mathrm{a}}$ & .07500 & 4.80 & 3.39 & 2.77 & 2.40 & 2.00 & 1.41 & 1.15 & 1.00 & 1.40 & .99 & .81 & .70 & .99 & .70 & .57 & .49 \\
\hline & & Sept. & .18485 & 3.61 & 2.92 & 2.66 & 2.51 & 1.56 & 1.26 & 1.15 & 1.08 & 1.10 & .89 & .81 & .76 & .78 & .63 & .57 & .54 \\
\hline
\end{tabular}

${ }^{a}$ Models with an initial negative bend variance component estimate and re-estimated using standard Restricted Maximum Likelihood estimation methods. 
Table 12. Summary of blue sucker-adult power, required mean difference, and multiplier needed using current treatment mean difference at different bend/subsample levels for each gear type and month of the Habitat Assessment Monitoring Program.

[power $=0.8, \alpha=0.05$ ]

\begin{tabular}{|c|c|c|c|c|c|c|c|c|c|c|c|c|c|c|c|c|c|c|c|}
\hline \multirow{3}{*}{ Parameter } & \multirow{3}{*}{ Gear type } & \multirow{3}{*}{ Month } & \multirow{3}{*}{$\begin{array}{c}\text { Current } \\
\text { model } \\
\text { treatment } \\
\text { difference }\end{array}$} & \multicolumn{16}{|c|}{ Bend/subsample level } \\
\hline & & & & \multicolumn{4}{|c|}{4} & \multicolumn{4}{|c|}{20} & \multicolumn{4}{|c|}{40} & \multicolumn{4}{|c|}{80} \\
\hline & & & & 4 & 8 & 12 & 16 & 4 & 8 & 12 & 16 & 4 & 8 & 12 & 16 & 4 & 8 & 12 & 16 \\
\hline \multirow[t]{6}{*}{ Power } & Otter trawl & July & 0.00819 & 0.05 & 0.05 & 0.05 & 0.05 & 0.05 & 0.05 & 0.05 & 0.05 & 0.05 & 0.05 & 0.05 & 0.06 & 0.05 & 0.06 & 0.06 & 0.06 \\
\hline & & Aug. ${ }^{a}$ & .03448 & .07 & .10 & .12 & .15 & .19 & .33 & .46 & .57 & .33 & .58 & .75 & .86 & .58 & .87 & .96 & .99 \\
\hline & & Sept. & .00668 & .05 & .05 & .05 & .05 & .05 & .05 & .06 & .06 & .05 & .06 & .06 & .07 & .06 & .07 & .07 & .08 \\
\hline & Trammel net & July & .18464 & .06 & .06 & .06 & .06 & .09 & .11 & .12 & .12 & .14 & .17 & .19 & .19 & .23 & .29 & .32 & .34 \\
\hline & & Aug. ${ }^{a}$ & .07500 & .09 & .13 & .17 & .22 & .29 & .51 & .68 & .80 & .52 & .81 & .93 & .98 & .81 & .98 & 1.00 & 1.00 \\
\hline & & Sept. & .07303 & .06 & .07 & .08 & .09 & .13 & .18 & .22 & .25 & .22 & .32 & .39 & .44 & .38 & .56 & .66 & .73 \\
\hline \multirow{2}{*}{$\begin{array}{l}\text { Difference } \\
\text { needed for }\end{array}$} & Otter trawl & July & .00819 & .55 & .43 & .38 & .35 & .24 & .18 & .16 & .15 & .17 & .13 & .11 & .11 & .12 & .09 & .08 & .07 \\
\hline & & Aug. ${ }^{a}$ & .03448 & .22 & .15 & .12 & .11 & .09 & .06 & .05 & .04 & .06 & .04 & .04 & .03 & .04 & .03 & .03 & .02 \\
\hline \multirow{4}{*}{$\begin{array}{l}\text { power to } \\
\text { equal } 0.8\end{array}$} & & Sept. & .00668 & .32 & .24 & .20 & .18 & .13 & .10 & .08 & .07 & .09 & .07 & .06 & .05 & .07 & .05 & .04 & .04 \\
\hline & Trammel net & July & .18464 & 1.96 & 1.70 & 1.60 & 1.55 & .84 & .73 & .69 & .67 & .60 & .52 & .49 & .47 & .42 & .36 & .34 & .33 \\
\hline & & Aug. ${ }^{a}$ & .07500 & .36 & .25 & .21 & .18 & .15 & .11 & .09 & .07 & .11 & .07 & .06 & .05 & .07 & .05 & .04 & .04 \\
\hline & & Sept. & .07303 & .57 & .45 & .40 & .37 & .25 & .19 & .17 & .16 & .17 & .14 & .12 & .11 & .12 & .10 & .09 & .08 \\
\hline \multirow{3}{*}{$\begin{array}{l}\text { Multiplier } \\
\text { needed for } \\
\text { power to }\end{array}$} & Otter trawl & July & .00819 & 67.55 & 52.19 & 45.94 & 42.47 & 29.17 & 22.53 & 19.84 & 18.34 & 20.56 & 15.88 & 13.98 & 12.93 & 14.51 & 11.21 & 9.87 & 9.13 \\
\hline & & Aug. ${ }^{\mathrm{a}}$ & .03448 & 6.28 & 4.44 & 3.62 & 3.14 & 2.61 & 1.85 & 1.51 & 1.30 & 1.83 & 1.30 & 1.06 & .92 & 1.29 & .91 & .75 & .65 \\
\hline & & Sept. & .00668 & 47.91 & 35.18 & 29.75 & 26.62 & 19.92 & 14.62 & 12.37 & 11.07 & 13.99 & 10.27 & 8.69 & 7.77 & 9.86 & 7.24 & 6.12 & 5.48 \\
\hline \multirow[t]{3}{*}{ equal 0.8} & Trammel net & July & .18464 & 10.59 & 9.19 & 8.68 & 8.41 & 4.57 & 3.97 & 3.75 & 3.63 & 3.22 & 2.80 & 2.64 & 2.56 & 2.28 & 1.98 & 1.86 & 1.81 \\
\hline & & Aug. ${ }^{a}$ & .07500 & 4.80 & 3.39 & 2.77 & 2.40 & 2.00 & 1.41 & 1.15 & 1.00 & 1.40 & .99 & .81 & .70 & .99 & .70 & .57 & .49 \\
\hline & & Sept. & .07303 & 7.85 & 6.15 & 5.46 & 5.09 & 3.39 & 2.65 & 2.36 & 2.20 & 2.39 & 1.87 & 1.66 & 1.55 & 1.69 & 1.32 & 1.17 & 1.09 \\
\hline
\end{tabular}

${ }^{a}$ Models with an initial negative bend variance component estimate and re-estimated using standard Restricted Maximum Likelihood estimation methods. 
Table 13. Summary of the blue sucker-juvenile power, required mean difference, and multiplier needed using current treatment mean difference at different bend/subsample levels for each gear type and month of the Habitat Assessment Monitoring Program.

[power $=0.8, \alpha=0.05]$

\begin{tabular}{|c|c|c|c|c|c|c|c|c|c|c|c|c|c|c|c|c|c|c|c|}
\hline \multirow{3}{*}{ Parameter } & \multirow{3}{*}{ Gear type } & \multirow{3}{*}{ Month } & \multirow{3}{*}{$\begin{array}{c}\text { Current } \\
\text { model } \\
\text { treatment } \\
\text { difference }\end{array}$} & \multicolumn{16}{|c|}{ Bend/subsample level } \\
\hline & & & & \multicolumn{4}{|c|}{4} & \multicolumn{4}{|c|}{20} & \multicolumn{4}{|c|}{40} & \multicolumn{4}{|c|}{80} \\
\hline & & & & 4 & 8 & 12 & 16 & 4 & 8 & 12 & 16 & 4 & 8 & 12 & 16 & 4 & 8 & 12 & 16 \\
\hline \multirow[t]{5}{*}{ Power } & Otter trawl & July & 0.00595 & 0.05 & 0.05 & 0.06 & 0.06 & 0.06 & 0.07 & 0.08 & 0.09 & 0.08 & 0.10 & 0.12 & 0.13 & 0.11 & 0.15 & 0.19 & 0.22 \\
\hline & & Aug. ${ }^{a}$ & .02674 & .10 & .15 & .19 & .24 & .33 & .55 & .71 & .82 & .57 & .85 & .95 & .98 & .86 & .99 & 1.00 & 1.00 \\
\hline & & Sept. ${ }^{b c}$ & .01972 & .09 & .13 & .17 & .21 & .31 & .54 & .71 & .83 & .55 & .84 & .95 & .99 & .85 & .99 & 1.00 & 1.00 \\
\hline & Trammel net & July $^{\mathrm{c}}$ & .00483 & .05 & .05 & .05 & .05 & .06 & .06 & .07 & .07 & .06 & .07 & .08 & .09 & .07 & .09 & .11 & .14 \\
\hline & & Sept. ${ }^{a}$ & .11182 & .18 & .24 & .27 & .29 & .68 & .82 & .88 & .90 & .93 & .98 & .99 & 1.00 & 1.00 & 1.00 & 1.00 & 1.00 \\
\hline \multirow{2}{*}{$\begin{array}{l}\text { Difference } \\
\text { needed for }\end{array}$} & Otter trawl & July & .00595 & .11 & .08 & .07 & .06 & .05 & .04 & .03 & .03 & .03 & .03 & .02 & .02 & .02 & .02 & .02 & .01 \\
\hline & & Aug. ${ }^{a}$ & .02674 & .12 & .08 & .07 & .06 & .05 & .04 & .03 & .03 & .04 & .03 & .02 & .02 & .02 & .02 & .01 & .01 \\
\hline \multirow{3}{*}{$\begin{array}{l}\text { power to } \\
\text { equal } 0.8\end{array}$} & & Sept. ${ }^{b c}$ & .01972 & .10 & .07 & .06 & .05 & .04 & .03 & .02 & .02 & .03 & .02 & .02 & .01 & .02 & .01 & .01 & .01 \\
\hline & Trammel net & July $^{\mathrm{c}}$ & .00483 & .15 & .10 & .09 & .07 & .06 & .05 & .04 & .03 & .04 & .03 & .03 & .02 & .03 & .02 & .02 & .02 \\
\hline & & Sept. ${ }^{a}$ & .11182 & .30 & .25 & .23 & .22 & .13 & .11 & .10 & .10 & .09 & .08 & .07 & .07 & .06 & .05 & .05 & .05 \\
\hline \multirow{5}{*}{$\begin{array}{l}\text { Multiplier } \\
\text { needed for } \\
\text { power to } \\
\text { equal } 0.8\end{array}$} & Otter trawl & July & .00595 & 19.00 & 14.13 & 12.08 & 10.91 & 8.20 & 6.10 & 5.21 & 4.71 & 5.78 & 4.30 & 3.67 & 3.32 & 4.08 & 3.04 & 2.59 & 2.34 \\
\hline & & Aug. ${ }^{a}$ & .02674 & 4.30 & 3.09 & 2.57 & 2.26 & 1.86 & 1.34 & 1.11 & .98 & 1.31 & .94 & .78 & .69 & .92 & .66 & .55 & .49 \\
\hline & & Sept. ${ }^{b c}$ & .01972 & 5.03 & 3.56 & 2.90 & 2.51 & 1.92 & 1.36 & 1.11 & .96 & 1.34 & .95 & .77 & .67 & .94 & .67 & .54 & .47 \\
\hline & Trammel net & July $^{\mathrm{c}}$ & .00483 & 30.54 & 21.59 & 17.63 & 15.27 & 13.19 & 9.32 & 7.61 & 6.59 & 9.29 & 6.57 & 5.37 & 4.65 & 6.56 & 4.64 & 3.79 & 3.28 \\
\hline & & Sept. ${ }^{a}$ & .11182 & 2.68 & 2.24 & 2.08 & 1.99 & 1.16 & .97 & .90 & .86 & .82 & .68 & .63 & .61 & .58 & .48 & .45 & .43 \\
\hline
\end{tabular}

${ }^{a}$ Models with the treated mean response of zero.

${ }^{b}$ Models with an initial negative bend variance component estimate and re-estimated using standard Restricted Maximum Likelihood estimation methods.

${ }^{\mathrm{c}}$ Models with the untreated mean response of zero. 
Table 14. Summary of the pallid sturgeon-all power, required mean difference, and multiplier needed using current treatment mean difference at different bend/subsample levels for each gear type and month of the Habitat Assessment Monitoring Program.

[power $=0.8, \alpha=0.05]$

\begin{tabular}{|c|c|c|c|c|c|c|c|c|c|c|c|c|c|c|c|c|c|c|c|}
\hline \multirow{3}{*}{ Parameter } & \multirow{3}{*}{ Gear type } & \multirow{3}{*}{ Month } & \multirow{3}{*}{$\begin{array}{c}\text { Current } \\
\text { model } \\
\text { treatment } \\
\text { difference }\end{array}$} & \multicolumn{16}{|c|}{ Bend/subsample level } \\
\hline & & & & \multicolumn{4}{|c|}{4} & \multicolumn{4}{|c|}{20} & \multicolumn{4}{|c|}{40} & \multicolumn{4}{|c|}{80} \\
\hline & & & & 4 & 8 & 12 & 16 & 4 & 8 & 12 & 16 & 4 & 8 & 12 & 16 & 4 & 8 & 12 & 16 \\
\hline \multirow[t]{4}{*}{ Power } & Otter trawl & July $^{\mathrm{a}}$ & 0.03012 & 0.25 & 0.44 & 0.61 & 0.73 & 0.85 & 0.99 & 1.00 & 1.00 & 0.99 & 1.00 & 1.00 & 1.00 & 1.00 & 1.00 & 1.00 & 1.00 \\
\hline & & Sept. ${ }^{a}$ & .02103 & .09 & .13 & .15 & .17 & .35 & .54 & .66 & .73 & .62 & .84 & .92 & .96 & .90 & .99 & 1.00 & 1.00 \\
\hline & Trammel net & July ${ }^{\mathrm{b}}$ & .03349 & .14 & .18 & .21 & .22 & .59 & .76 & .83 & .87 & .88 & .97 & .99 & .99 & .99 & 1.00 & 1.00 & 1.00 \\
\hline & & Aug. ${ }^{c}$ & .02296 & .09 & .13 & .16 & .20 & .31 & .53 & .70 & .82 & .55 & .83 & .95 & .98 & .84 & .99 & 1.00 & 1.00 \\
\hline Difference & Otter trawl & July $^{\mathrm{a}}$ & .03012 & .07 & .05 & .04 & .03 & .03 & .02 & .02 & .01 & .02 & .01 & .01 & .01 & .01 & .01 & .01 & .01 \\
\hline needed for & & Sept. ${ }^{a}$ & .02103 & .10 & .07 & .07 & .06 & .04 & .03 & .02 & .02 & .03 & .02 & .02 & .02 & .02 & .01 & .01 & .01 \\
\hline power to & Trammel net & July $^{\mathrm{b}}$ & .03349 & .11 & .09 & .08 & .08 & .04 & .04 & .03 & .03 & .03 & .02 & .02 & .02 & .02 & .02 & .02 & .01 \\
\hline equal 0.8 & & Aug. ${ }^{c}$ & .02296 & .12 & .08 & .07 & .06 & .04 & .03 & .03 & .02 & .03 & .02 & .02 & .02 & .02 & .02 & .01 & .01 \\
\hline Multiplier & Otter trawl & July $^{\mathrm{a}}$ & .03012 & 2.18 & 1.54 & 1.26 & 1.09 & .94 & .66 & .54 & .47 & .66 & .47 & .38 & .33 & .47 & .33 & .27 & .23 \\
\hline needed for & & Sept. ${ }^{a}$ & .02103 & 4.62 & 3.54 & 3.10 & 2.85 & 1.77 & 1.35 & 1.18 & 1.09 & 1.23 & .94 & .82 & .76 & .87 & .66 & .58 & .53 \\
\hline power to & Trammel net & July $^{\mathrm{b}}$ & .03349 & 3.37 & 2.75 & 2.51 & 2.38 & 1.29 & 1.05 & .96 & .91 & .90 & .73 & .67 & .63 & .63 & .51 & .47 & .45 \\
\hline equal 0.8 & & Aug. ${ }^{c}$ & .02296 & 5.06 & 3.59 & 2.94 & 2.55 & 1.93 & 1.37 & 1.12 & .97 & 1.35 & .96 & .78 & .68 & .95 & .67 & .55 & .48 \\
\hline
\end{tabular}

${ }^{a}$ Models with an initial negative bend variance component estimate and re-estimated using standard Restricted Maximum Likelihood estimation methods.

${ }^{\mathrm{b}}$ Models with the treated mean response of zero.

${ }^{\mathrm{c}}$ Models with the untreated mean response of zero. 
Table 15. Summary of the pallid sturgeon-adult power, required mean difference, and multiplier needed using current treatment mean difference at different bend/subsample levels for each gear type and month of the Habitat Assessment Monitoring Program.

[power $=0.8, \alpha=0.05]$

\begin{tabular}{|c|c|c|c|c|c|c|c|c|c|c|c|c|c|c|c|c|c|c|c|}
\hline \multirow{3}{*}{ Parameter } & \multirow{3}{*}{ Gear type } & \multirow{3}{*}{ Month } & \multirow{3}{*}{$\begin{array}{c}\text { Current } \\
\text { model } \\
\text { treatment } \\
\text { difference }\end{array}$} & \multicolumn{16}{|c|}{ Bend/subsample level } \\
\hline & & & & \multicolumn{4}{|c|}{4} & \multicolumn{4}{|c|}{20} & \multicolumn{4}{|c|}{40} & \multicolumn{4}{|c|}{80} \\
\hline & & & & 4 & 8 & 12 & 16 & 4 & 8 & 12 & 16 & 4 & 8 & 12 & 16 & 4 & 8 & 12 & 16 \\
\hline Power & Otter trawl & July ab & 0.11906 & 0.58 & 0.86 & 0.96 & 0.99 & 1.00 & 1.00 & 1.00 & 1.00 & 1.00 & 1.00 & 1.00 & 1.00 & 1.00 & 1.00 & 1.00 & 1.00 \\
\hline $\begin{array}{l}\text { Difference } \\
\text { needed for } \\
\text { power to } \\
\text { equal } 0.8\end{array}$ & Otter trawl & July ab & .11906 & .16 & .11 & .09 & .08 & .06 & .04 & .03 & .03 & .04 & .03 & .02 & .02 & .03 & .02 & .02 & .01 \\
\hline $\begin{array}{l}\text { Multiplier } \\
\text { needed for } \\
\text { power to } \\
\text { equal } 0.8\end{array}$ & Otter trawl & July ab & .11906 & 1.30 & .92 & .75 & .65 & .50 & .35 & .29 & .25 & .35 & .25 & .20 & .17 & .24 & .17 & .14 & .12 \\
\hline
\end{tabular}

${ }^{a}$ Models with an initial negative bend variance component estimate and re-estimated using standard Restricted Maximum Likelihood estimation methods.

${ }^{\mathrm{b}}$ Models with the untreated mean response of zero. 


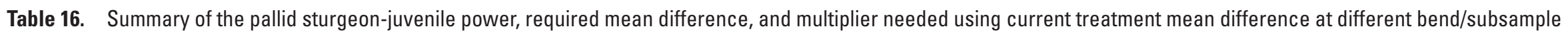
levels for each gear type and month of the Habitat Assessment Monitoring Program.

[power $=0.8, \alpha=0.05]$

\begin{tabular}{|c|c|c|c|c|c|c|c|c|c|c|c|c|c|c|c|c|c|c|c|}
\hline \multirow{3}{*}{ Parameter } & \multirow{3}{*}{ Gear type } & \multirow{3}{*}{ Month } & \multirow{3}{*}{$\begin{array}{c}\text { Current } \\
\text { model } \\
\text { treatment } \\
\text { difference }\end{array}$} & \multicolumn{16}{|c|}{ Bend/subsample level } \\
\hline & & & & \multicolumn{4}{|c|}{4} & \multicolumn{4}{|c|}{20} & \multicolumn{4}{|c|}{40} & \multicolumn{4}{|c|}{80} \\
\hline & & & & 4 & 8 & 12 & 16 & 4 & 8 & 12 & 16 & 4 & 8 & 12 & 16 & 4 & 8 & 12 & 16 \\
\hline \multirow[t]{4}{*}{ Power } & Otter trawl & July a $^{a}$ & 0.00035 & 0.05 & 0.05 & 0.05 & 0.05 & 0.05 & 0.05 & 0.05 & 0.05 & 0.05 & 0.05 & 0.05 & 0.05 & 0.05 & 0.05 & 0.05 & 0.05 \\
\hline & & Sept. ${ }^{b}$ & .02103 & .09 & .13 & .15 & .17 & .35 & .54 & .66 & .73 & .62 & .84 & .92 & .96 & .90 & .99 & 1.00 & 1.00 \\
\hline & Trammel net & July ${ }^{b}$ & .03349 & .14 & .18 & .21 & .22 & .59 & .76 & .83 & .87 & .88 & .97 & .99 & .99 & .99 & 1.00 & 1.00 & 1.00 \\
\hline & & Aug. ${ }^{c}$ & .02296 & .09 & .13 & .16 & .20 & .31 & .53 & .70 & .82 & .55 & .83 & .95 & .98 & .84 & .99 & 1.00 & 1.00 \\
\hline Difference & Otter trawl & July a & .00035 & .06 & .04 & .03 & .03 & .02 & .02 & .01 & .01 & .02 & .01 & .01 & .01 & .01 & .01 & .01 & .01 \\
\hline needed for & & Sept. ${ }^{b}$ & .02103 & .10 & .07 & .07 & .06 & .04 & .03 & .02 & .02 & .03 & .02 & .02 & .02 & .02 & .01 & .01 & .01 \\
\hline power to & Trammel net & July $^{\mathrm{b}}$ & .03349 & .11 & .09 & .08 & .08 & .04 & .04 & .03 & .03 & .03 & .02 & .02 & .02 & .02 & .02 & .02 & .01 \\
\hline equal 0.8 & & Aug. ${ }^{c}$ & .02296 & .12 & .08 & .07 & .06 & .04 & .03 & .03 & .02 & .03 & .02 & .02 & .02 & .02 & .02 & .01 & .01 \\
\hline Multiplier & Otter trawl & July $^{a}$ & .00035 & 160.89 & 113.77 & 92.89 & 80.45 & 69.47 & 49.12 & 40.11 & 34.74 & 48.96 & 34.62 & 28.27 & 24.48 & 34.57 & 24.44 & 19.96 & 17.28 \\
\hline needed for & & Sept. ${ }^{b}$ & .02103 & 4.62 & 3.54 & 3.10 & 2.85 & 1.77 & 1.35 & 1.18 & 1.09 & 1.23 & .94 & .82 & .76 & .87 & .66 & .58 & .53 \\
\hline power to & Trammel net & July b & .03349 & 3.37 & 2.75 & 2.51 & 2.38 & 1.29 & 1.05 & .96 & .91 & .90 & .73 & .67 & .63 & .63 & .51 & .47 & .45 \\
\hline equal 0.8 & & Aug. ${ }^{c}$ & .02296 & 5.06 & 3.59 & 2.94 & 2.55 & 1.93 & 1.37 & 1.12 & .97 & 1.35 & .96 & .78 & .68 & .95 & .67 & .55 & .48 \\
\hline
\end{tabular}

a Models with an initial negative bend variance component estimate and re-estimated using standard Restricted Maximum Likelihood estimation methods.

${ }^{\mathrm{b}}$ Models with the treated mean response of zero.

${ }^{\mathrm{c}}$ Models with the untreated mean response of zero. 


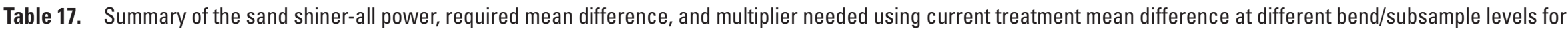
each gear type and month of the Habitat Assessment Monitoring Program.

[power $=0.8, \alpha=0.05]$

\begin{tabular}{|c|c|c|c|c|c|c|c|c|c|c|c|c|c|c|c|c|c|c|c|}
\hline \multirow{3}{*}{ Parameter } & \multirow{3}{*}{ Gear type } & \multirow{3}{*}{ Month } & \multirow{3}{*}{$\begin{array}{c}\text { Current } \\
\text { model } \\
\text { treatment } \\
\text { difference }\end{array}$} & \multicolumn{16}{|c|}{ Bend/subsample level } \\
\hline & & & & \multicolumn{4}{|c|}{4} & \multicolumn{4}{|c|}{20} & \multicolumn{4}{|c|}{40} & \multicolumn{4}{|c|}{80} \\
\hline & & & & 4 & 8 & 12 & 16 & 4 & 8 & 12 & 16 & 4 & 8 & 12 & 16 & 4 & 8 & 12 & 16 \\
\hline \multirow[t]{5}{*}{ Power } & Mini-fyke net & Aug. & 6.11675 & 0.08 & 0.10 & 0.11 & 0.12 & 0.24 & 0.35 & 0.42 & 0.47 & 0.43 & 0.61 & 0.71 & 0.76 & 0.72 & 0.89 & 0.94 & 0.97 \\
\hline & & Sept. & 1.22988 & .09 & .11 & .12 & .13 & .26 & .39 & .47 & .52 & .47 & .67 & .76 & .82 & .76 & .92 & .97 & .98 \\
\hline & Otter trawl & July a & .58212 & .10 & .13 & .16 & .19 & .37 & .58 & .70 & .78 & .64 & .87 & .95 & .98 & .91 & .99 & 1.00 & 1.00 \\
\hline & & Aug. ${ }^{b}$ & .01613 & .06 & .07 & .08 & .09 & .11 & .18 & .24 & .30 & .18 & .31 & .43 & .54 & .31 & .54 & .71 & .83 \\
\hline & & Sept. ${ }^{a b}$ & .03921 & .12 & .19 & .27 & .34 & .51 & .80 & .93 & .98 & .81 & .98 & 1.00 & 1.00 & .98 & 1.00 & 1.00 & 1.00 \\
\hline \multirow{5}{*}{$\begin{array}{l}\text { Difference } \\
\text { needed for } \\
\text { power to } \\
\text { equal } 0.8\end{array}$} & Mini-fyke net & Aug. & 6.11675 & 32.72 & 26.06 & 23.42 & 21.98 & 13.60 & 10.83 & 9.73 & 9.14 & 9.56 & 7.61 & 6.84 & 6.42 & 6.74 & 5.36 & 4.82 & 4.52 \\
\hline & & Sept. & 1.22988 & 6.26 & 4.94 & 4.41 & 4.12 & 2.60 & 2.05 & 1.83 & 1.71 & 1.83 & 1.44 & 1.29 & 1.20 & 1.29 & 1.02 & .91 & .85 \\
\hline & Otter trawl & July a & .58212 & 2.64 & 1.99 & 1.71 & 1.56 & 1.01 & .76 & .65 & .60 & .70 & .53 & .46 & .42 & .49 & .37 & .32 & .29 \\
\hline & & Aug. ${ }^{b}$ & .01613 & .15 & .11 & .09 & .08 & .06 & .04 & .04 & .03 & .04 & .03 & .03 & .02 & .03 & .02 & .02 & .02 \\
\hline & & Sept. ${ }^{\text {a b }}$ & .03921 & .14 & .10 & .08 & .07 & .06 & .04 & .03 & .03 & .04 & .03 & .02 & .02 & .03 & .02 & .02 & .01 \\
\hline \multirow{5}{*}{$\begin{array}{l}\text { Multiplier } \\
\text { needed for } \\
\text { power to } \\
\text { equal } 0.8\end{array}$} & Mini-fyke net & Aug. & 6.11675 & 5.35 & 4.26 & 3.83 & 3.59 & 2.22 & 1.77 & 1.59 & 1.49 & 1.56 & 1.24 & 1.12 & 1.05 & 1.10 & .88 & .79 & .74 \\
\hline & & Sept. & 1.22988 & 5.09 & 4.02 & 3.59 & 3.35 & 2.12 & 1.67 & 1.49 & 1.39 & 1.49 & 1.17 & 1.05 & .98 & 1.05 & .83 & .74 & .69 \\
\hline & Otter trawl & July a & .58212 & 4.53 & 3.41 & 2.94 & 2.68 & 1.73 & 1.30 & 1.12 & 1.02 & 1.21 & .91 & .78 & .71 & .85 & .64 & .55 & .50 \\
\hline & & Aug.b & .01613 & 9.34 & 6.60 & 5.39 & 4.67 & 3.88 & 2.74 & 2.24 & 1.94 & 2.73 & 1.93 & 1.57 & 1.36 & 1.92 & 1.36 & 1.11 & .96 \\
\hline & & Sept. ${ }^{a b}$ & .03921 & 3.69 & 2.61 & 2.13 & 1.84 & 1.41 & 1.00 & .81 & .70 & .98 & .69 & .57 & .49 & .69 & .49 & .40 & .35 \\
\hline
\end{tabular}

${ }^{a}$ Models with the treated mean response of zero.

${ }^{\mathrm{b}}$ Models with an initial negative bend variance component estimate and re-estimated using standard Restricted Maximum Likelihood estimation methods. 


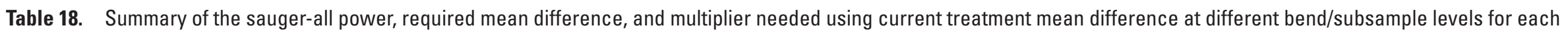
gear type and month of the Habitat Assessment Monitoring Program.

[power $=0.8, \alpha=0.05$ ]

\begin{tabular}{|c|c|c|c|c|c|c|c|c|c|c|c|c|c|c|c|c|c|c|c|}
\hline \multirow{3}{*}{ Parameter } & \multirow{3}{*}{ Gear type } & \multirow{3}{*}{ Month } & \multirow{3}{*}{$\begin{array}{c}\text { Current } \\
\text { model } \\
\text { treatment } \\
\text { difference }\end{array}$} & \multicolumn{16}{|c|}{ Bend/subsample level } \\
\hline & & & & \multicolumn{4}{|c|}{4} & \multicolumn{4}{|c|}{20} & \multicolumn{4}{|c|}{40} & \multicolumn{4}{|c|}{80} \\
\hline & & & & 4 & 8 & 12 & 16 & 4 & 8 & 12 & 16 & 4 & 8 & 12 & 16 & 4 & 8 & 12 & 16 \\
\hline \multirow[t]{8}{*}{ Power } & Mini-fyke net & Aug. ${ }^{a}$ & 0.02458 & 0.11 & 0.18 & 0.24 & 0.30 & 0.41 & 0.69 & 0.85 & 0.93 & 0.70 & 0.94 & 0.99 & 1.00 & 0.94 & 1.00 & 1.00 & 1.00 \\
\hline & & Sept. ${ }^{b}$ & .01740 & .09 & .12 & .14 & .16 & .30 & .49 & .62 & .71 & .54 & .79 & .90 & .95 & .83 & .98 & 1.00 & 1.00 \\
\hline & Otter trawl & July & .01108 & .05 & .06 & .06 & .06 & .07 & .09 & .11 & .12 & .10 & .14 & .17 & .19 & .15 & .23 & .29 & .34 \\
\hline & & Aug. & .00494 & .05 & .05 & .05 & .05 & .06 & .06 & .07 & .07 & .06 & .07 & .08 & .09 & .08 & .10 & .12 & .14 \\
\hline & & Sept. ${ }^{a}$ & .01847 & .07 & .08 & .10 & .12 & .15 & .25 & .35 & .44 & .25 & .44 & .61 & .73 & .45 & .73 & .89 & .95 \\
\hline & Trammel net & July a & .00002 & .05 & .05 & .05 & .05 & .05 & .05 & .05 & .05 & .05 & .05 & .05 & .05 & .05 & .05 & .05 & .05 \\
\hline & & Aug. ${ }^{c}$ & .02977 & .08 & .11 & .13 & .14 & .27 & .43 & .54 & .61 & .49 & .72 & .84 & .90 & .78 & .95 & .99 & 1.00 \\
\hline & & Sept. ${ }^{a b}$ & .04733 & .13 & .22 & .30 & .38 & .58 & .86 & .96 & .99 & .87 & .99 & 1.00 & 1.00 & .99 & 1.00 & 1.00 & 1.00 \\
\hline \multirow{8}{*}{$\begin{array}{l}\text { Difference } \\
\text { needed for } \\
\text { power to } \\
\text { equal } 0.8\end{array}$} & Mini-fyke net & Aug. ${ }^{a}$ & .02458 & .10 & .07 & .06 & .05 & .04 & .03 & .02 & .02 & .03 & .02 & .02 & .01 & .02 & .01 & .01 & .01 \\
\hline & & Sept. ${ }^{b}$ & .01740 & .09 & .07 & .06 & .05 & .03 & .03 & .02 & .02 & .02 & .02 & .02 & .01 & .02 & .01 & .01 & .01 \\
\hline & Otter trawl & July & .01108 & .16 & .12 & .10 & .09 & .07 & .05 & .04 & .04 & .05 & .04 & .03 & .03 & .03 & .03 & .02 & .02 \\
\hline & & Aug. & .00494 & .14 & .10 & .09 & .08 & .06 & .04 & .04 & .03 & .04 & .03 & .03 & .02 & .03 & .02 & .02 & .02 \\
\hline & & Sept. ${ }^{a}$ & .01847 & .14 & .10 & .08 & .07 & .06 & .04 & .03 & .03 & .04 & .03 & .02 & .02 & .03 & .02 & .02 & .01 \\
\hline & Trammel net & July a & .00002 & .10 & .07 & .06 & .05 & .04 & .03 & .03 & .02 & .03 & .02 & .02 & .02 & .02 & .02 & .01 & .01 \\
\hline & & Aug. ${ }^{c}$ & .02977 & .16 & .12 & .11 & .10 & .06 & .05 & .04 & .04 & .04 & .03 & .03 & .03 & .03 & .02 & .02 & .02 \\
\hline & & Sept. ${ }^{a b}$ & .04733 & .16 & .11 & .09 & .08 & .06 & .04 & .04 & .03 & .04 & .03 & .02 & .02 & .03 & .02 & .02 & .02 \\
\hline \multirow{8}{*}{$\begin{array}{l}\text { Multiplier } \\
\text { needed for } \\
\text { power to } \\
\text { equal } 0.8\end{array}$} & Mini-fyke net & Aug. ${ }^{a}$ & .02458 & 3.88 & 2.74 & 2.24 & 1.94 & 1.61 & 1.14 & .93 & .81 & 1.13 & .80 & .65 & .57 & .80 & .56 & .46 & .40 \\
\hline & & Sept. ${ }^{b}$ & .01740 & 5.12 & 3.81 & 3.25 & 2.94 & 1.96 & 1.45 & 1.24 & 1.12 & 1.36 & 1.01 & .87 & .78 & .96 & .71 & .61 & .55 \\
\hline & Otter trawl & July & .01108 & 14.29 & 10.74 & 9.26 & 8.43 & 6.17 & 4.64 & 4.00 & 3.64 & 4.36 & 3.27 & 2.82 & 2.56 & 3.07 & 2.31 & 1.99 & 1.81 \\
\hline & & Aug. & .00494 & 28.86 & 21.18 & 17.91 & 16.02 & 12.00 & 8.81 & 7.44 & 6.66 & 8.43 & 6.19 & 5.23 & 4.68 & 5.94 & 4.36 & 3.69 & 3.30 \\
\hline & & Sept. ${ }^{\text {a }}$ & .01847 & 7.45 & 5.27 & 4.30 & 3.73 & 3.10 & 2.19 & 1.79 & 1.55 & 2.18 & 1.54 & 1.26 & 1.09 & 1.53 & 1.08 & .89 & .77 \\
\hline & Trammel net & July a & .00002 & 4,692 & 3,318 & 2,709 & 2,346 & 2,026 & 1,433 & 1,170 & 1,013 & 1,428 & 1,010 & 824 & 714 & 1,008 & 713 & 582 & 504 \\
\hline & & Aug. ${ }^{c}$ & .02977 & 5.45 & 4.12 & 3.57 & 3.26 & 2.08 & 1.57 & 1.36 & 1.24 & 1.45 & 1.10 & .95 & .87 & 1.02 & .77 & .67 & .61 \\
\hline & & Sept. ${ }^{a b}$ & .04733 & 3.41 & 2.41 & 1.97 & 1.71 & 1.30 & .92 & .75 & .65 & .91 & .64 & .52 & .45 & .64 & .45 & .37 & .32 \\
\hline
\end{tabular}

${ }^{a}$ Models with an initial negative bend variance component estimate and re-estimated using standard Restricted Maximum Likelihood estimation methods.

${ }^{\mathrm{b}}$ Models with the untreated mean response of zero.

${ }^{\mathrm{c}}$ Models with the treated mean response of zero. 
Table 19. Summary of the sauger-adult power, required mean difference, and multiplier needed using current treatment mean difference at different bend/subsample levels for each gear type and month of the Habitat Assessment Monitoring Program.

[power $=0.8, \alpha=0.05$ ]

\begin{tabular}{|c|c|c|c|c|c|c|c|c|c|c|c|c|c|c|c|c|c|c|c|}
\hline \multirow{3}{*}{ Parameter } & \multirow{3}{*}{ Gear type } & \multirow{3}{*}{ Month } & \multirow{3}{*}{$\begin{array}{c}\text { Current } \\
\text { model } \\
\text { treatment } \\
\text { difference }\end{array}$} & \multicolumn{16}{|c|}{ Bend/subsample level } \\
\hline & & & & \multicolumn{4}{|c|}{4} & \multicolumn{4}{|c|}{20} & \multicolumn{4}{|c|}{40} & \multicolumn{4}{|c|}{80} \\
\hline & & & & 4 & 8 & 12 & 16 & 4 & 8 & 12 & 16 & 4 & 8 & 12 & 16 & 4 & 8 & 12 & 16 \\
\hline \multirow[t]{5}{*}{ Power } & Otter trawl & Aug. & 0.00494 & 0.05 & 0.05 & 0.05 & 0.05 & 0.06 & 0.06 & 0.07 & 0.07 & 0.06 & 0.07 & 0.08 & 0.09 & 0.08 & 0.10 & 0.12 & 0.14 \\
\hline & & Sept. ${ }^{a}$ & .01860 & .09 & .13 & .15 & .17 & .35 & .54 & .66 & .73 & .62 & .84 & .92 & .96 & .90 & .99 & 1.00 & 1.00 \\
\hline & Trammel net & July $^{\mathrm{b}}$ & .00002 & .05 & .05 & .05 & .05 & .05 & .05 & .05 & .05 & .05 & .05 & .05 & .05 & .05 & .05 & .05 & .05 \\
\hline & & Aug. ${ }^{a}$ & .02977 & .08 & .11 & .13 & .14 & .27 & .43 & .54 & .61 & .49 & .72 & .84 & .90 & .78 & .95 & .99 & 1.00 \\
\hline & & Sept. ${ }^{b c}$ & .04733 & .13 & .22 & .30 & .38 & .58 & .86 & .96 & .99 & .87 & .99 & 1.00 & 1.00 & .99 & 1.00 & 1.00 & 1.00 \\
\hline \multirow{5}{*}{$\begin{array}{l}\text { Difference } \\
\text { needed for } \\
\text { power to } \\
\text { equal } 0.8\end{array}$} & Otter trawl & Aug. & .00494 & .14 & .10 & .09 & .08 & .06 & .04 & .04 & .03 & .04 & .03 & .03 & .02 & .03 & .02 & .02 & .02 \\
\hline & & Sept. ${ }^{a}$ & .01860 & .09 & .07 & .06 & .05 & .03 & .03 & .02 & .02 & .02 & .02 & .02 & .01 & .02 & .01 & .01 & .01 \\
\hline & Trammel net & July $^{\mathrm{b}}$ & .00002 & .10 & .07 & .06 & .05 & .04 & .03 & .03 & .02 & .03 & .02 & .02 & .02 & .02 & .02 & .01 & .01 \\
\hline & & Aug. ${ }^{a}$ & .02977 & .16 & .12 & .11 & .10 & .06 & .05 & .04 & .04 & .04 & .03 & .03 & .03 & .03 & .02 & .02 & .02 \\
\hline & & Sept. ${ }^{b c}$ & .04733 & .16 & .11 & .09 & .08 & .06 & .04 & .04 & .03 & .04 & .03 & .02 & .02 & .03 & .02 & .02 & .02 \\
\hline \multirow{5}{*}{$\begin{array}{l}\text { Multiplier } \\
\text { needed for } \\
\text { power to } \\
\text { equal } 0.8\end{array}$} & Otter trawl & Aug. & .00494 & 28.86 & 21.18 & 17.91 & 16.02 & 12.00 & 8.81 & 7.44 & 6.66 & 8.43 & 6.19 & 5.23 & 4.68 & 5.94 & 4.36 & 3.69 & 3.30 \\
\hline & & Sept. ${ }^{a}$ & .01860 & 4.62 & 3.54 & 3.10 & 2.85 & 1.77 & 1.35 & 1.18 & 1.09 & 1.23 & .94 & .82 & .76 & .87 & .66 & .58 & .53 \\
\hline & Trammel net & July $^{\mathrm{b}}$ & .00002 & 4,692 & 3,318 & 2,709 & 2,346 & 2,026 & 1,433 & 1,170 & 1,013 & 1,428 & 1,010 & 824 & 714 & 1,008 & 713 & 582 & 504 \\
\hline & & Aug. ${ }^{a}$ & .02977 & 5.45 & 4.12 & 3.57 & 3.26 & 2.08 & 1.57 & 1.36 & 1.24 & 1.45 & 1.10 & .95 & .87 & 1.02 & .77 & .67 & .61 \\
\hline & & Sept. ${ }^{b c}$ & .04733 & 3.41 & 2.41 & 1.97 & 1.71 & 1.30 & .92 & .75 & .65 & .91 & .64 & .52 & .45 & .64 & .45 & .37 & .32 \\
\hline
\end{tabular}

\footnotetext{
${ }^{a}$ Models with the treated mean response of zero.

${ }^{\mathrm{b}}$ Models with an initial negative bend variance component estimate and re-estimated using standard Restricted Maximum Likelihood estimation methods.

${ }^{\mathrm{c}}$ Models with the untreated mean response of zero.
} 
Table 20. Summary of the sauger-juvenile power, required mean difference, and multiplier needed using current treatment mean difference at different bend/subsample levels for each gear type and month of the Habitat Assessment Monitoring Program.

[power $=0.8, \alpha=0.05]$

\begin{tabular}{|c|c|c|c|c|c|c|c|c|c|c|c|c|c|c|c|c|c|c|c|}
\hline \multirow{3}{*}{ Parameter } & \multirow{3}{*}{ Gear type } & \multirow{3}{*}{ Month } & \multirow{3}{*}{$\begin{array}{c}\text { Current } \\
\text { model } \\
\text { treatment } \\
\text { difference }\end{array}$} & \multicolumn{16}{|c|}{ Bend/subsample level } \\
\hline & & & & \multicolumn{4}{|c|}{4} & \multicolumn{4}{|c|}{20} & \multicolumn{4}{|c|}{40} & \multicolumn{4}{|c|}{80} \\
\hline & & & & 4 & 8 & 12 & 16 & 4 & 8 & 12 & 16 & 4 & 8 & 12 & 16 & 4 & 8 & 12 & 16 \\
\hline \multirow[t]{4}{*}{ Power } & Mini-fyke net & Aug. ${ }^{a}$ & 0.02458 & 0.11 & 0.18 & 0.24 & 0.30 & 0.41 & 0.69 & 0.85 & 0.93 & 0.70 & 0.94 & 0.99 & 1.00 & 0.94 & 1.00 & 1.00 & 1.00 \\
\hline & & Sept. ${ }^{b}$ & .01740 & .09 & .12 & .14 & .16 & .30 & .49 & .62 & .71 & .54 & .79 & .90 & .95 & .83 & .98 & 1.00 & 1.00 \\
\hline & Otter trawl & July & .01108 & .05 & .06 & .06 & .06 & .07 & .09 & .11 & .12 & .10 & .14 & .17 & .19 & .15 & .23 & .29 & .34 \\
\hline & & Sept. ${ }^{a}$ & .00917 & .05 & .06 & .06 & .07 & .08 & .11 & .14 & .17 & .11 & .17 & .23 & .29 & .17 & .29 & .40 & .51 \\
\hline Difference & Mini-fyke net & Aug. ${ }^{a}$ & .02458 & .10 & .07 & .06 & .05 & .04 & .03 & .02 & .02 & .03 & .02 & .02 & .01 & .02 & .01 & .01 & .01 \\
\hline needed for & & Sept. ${ }^{b}$ & .01740 & .09 & .07 & .06 & .05 & .03 & .03 & .02 & .02 & .02 & .02 & .02 & .01 & .02 & .01 & .01 & .01 \\
\hline power to & Otter trawl & July & .01108 & .16 & .12 & .10 & .09 & .07 & .05 & .04 & .04 & .05 & .04 & .03 & .03 & .03 & .03 & .02 & .02 \\
\hline equal 0.8 & & Sept. ${ }^{a}$ & .00917 & .13 & .09 & .07 & .06 & .05 & .04 & .03 & .03 & .04 & .03 & .02 & .02 & .03 & .02 & .01 & .01 \\
\hline Multiplier & Mini-fyke net & Aug. ${ }^{a}$ & .02458 & 3.88 & 2.74 & 2.24 & 1.94 & 1.61 & 1.14 & .93 & .81 & 1.13 & .80 & .65 & .57 & .80 & .56 & .46 & .40 \\
\hline needed for & & Sept. ${ }^{b}$ & .01740 & 5.12 & 3.81 & 3.25 & 2.94 & 1.96 & 1.45 & 1.24 & 1.12 & 1.36 & 1.01 & .87 & .78 & .96 & .71 & .61 & .55 \\
\hline power to & Otter trawl & July & .01108 & 14.29 & 10.74 & 9.26 & 8.43 & 6.17 & 4.64 & 4.00 & 3.64 & 4.35 & 3.27 & 2.82 & 2.56 & 3.07 & 2.31 & 1.99 & 1.81 \\
\hline equal 0.8 & & Sept. ${ }^{a}$ & .00917 & 13.75 & 9.72 & 7.94 & 6.87 & 5.71 & 4.04 & 3.30 & 2.86 & 4.01 & 2.84 & 2.32 & 2.01 & 2.83 & 2.00 & 1.63 & 1.41 \\
\hline
\end{tabular}

${ }^{a}$ Models with an initial negative bend variance component estimate and re-estimated using standard Restricted Maximum Likelihood estimation methods.

${ }^{\mathrm{b}}$ Models with the treated mean response of zero. 


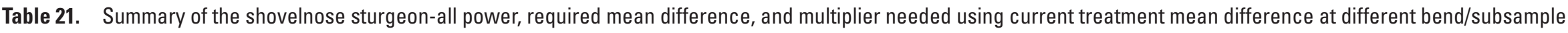
levels for each gear type and month of the Habitat Assessment Monitoring Program.

[power $=0.8, \alpha=0.05]$

\begin{tabular}{|c|c|c|c|c|c|c|c|c|c|c|c|c|c|c|c|c|c|c|c|}
\hline \multirow{3}{*}{ Parameter } & \multirow{3}{*}{ Gear type } & \multirow{3}{*}{ Month } & \multirow{3}{*}{$\begin{array}{c}\text { Current } \\
\text { model } \\
\text { treatment } \\
\text { difference }\end{array}$} & \multicolumn{16}{|c|}{ Bend/subsample level } \\
\hline & & & & \multicolumn{4}{|c|}{4} & \multicolumn{4}{|c|}{20} & \multicolumn{4}{|c|}{40} & \multicolumn{4}{|c|}{80} \\
\hline & & & & 4 & 8 & 12 & 16 & 4 & 8 & 12 & 16 & 4 & 8 & 12 & 16 & 4 & 8 & 12 & 16 \\
\hline \multirow[t]{6}{*}{ Power } & Otter trawl & July a & 0.10936 & 0.11 & 0.17 & 0.23 & 0.28 & 0.36 & 0.62 & 0.80 & 0.90 & 0.63 & 0.90 & 0.98 & 1.00 & 0.90 & 1.00 & 1.00 & 1.00 \\
\hline & & Aug. ${ }^{a}$ & .00013 & .05 & .05 & .05 & .05 & .05 & .05 & .05 & .05 & .05 & .05 & .05 & .05 & .05 & .05 & .05 & .05 \\
\hline & & Sept. & .17648 & .06 & .07 & .07 & .08 & .10 & .14 & .17 & .20 & .16 & .24 & .30 & .35 & .27 & .43 & .53 & .61 \\
\hline & Trammel net & July & .18063 & .05 & .06 & .06 & .06 & .07 & .08 & .09 & .10 & .09 & .12 & .14 & .15 & .14 & .19 & .23 & .26 \\
\hline & & Aug. ${ }^{a}$ & .05414 & .06 & .06 & .07 & .07 & .08 & .11 & .14 & .17 & .11 & .17 & .24 & .30 & .18 & .30 & .42 & .53 \\
\hline & & Sept. ${ }^{a}$ & .54461 & .23 & .40 & .55 & .67 & .80 & .98 & 1.00 & 1.00 & .98 & 1.00 & 1.00 & 1.00 & 1.00 & 1.00 & 1.00 & 1.00 \\
\hline \multirow{6}{*}{$\begin{array}{l}\text { Difference } \\
\text { needed for } \\
\text { power to } \\
\text { equal } 0.8\end{array}$} & Otter trawl & July a & .10936 & .44 & .31 & .25 & .22 & .19 & .13 & .11 & .10 & .13 & .09 & .08 & .07 & .09 & .07 & .05 & .05 \\
\hline & & Aug. ${ }^{a}$ & .00013 & .91 & .64 & .53 & .46 & .39 & .28 & .23 & .20 & .28 & .20 & .16 & .14 & .20 & .14 & .11 & .10 \\
\hline & & Sept. & .17648 & 1.71 & 1.29 & 1.12 & 1.03 & .74 & .56 & .49 & .44 & .52 & .39 & .34 & .31 & .37 & .28 & .24 & .22 \\
\hline & Trammel net & July & .18063 & 2.76 & 2.16 & 1.93 & 1.79 & 1.19 & .93 & .83 & .77 & .84 & .66 & .59 & .55 & .59 & .46 & .41 & .39 \\
\hline & & Aug. ${ }^{a}$ & .05414 & .69 & .49 & .40 & .35 & .30 & .21 & .17 & .15 & .21 & .15 & .12 & .11 & .15 & .11 & .09 & .07 \\
\hline & & Sept. ${ }^{a}$ & .54461 & 1.27 & .90 & .73 & .63 & .55 & .39 & .32 & .27 & .39 & .27 & .22 & .19 & .27 & .19 & .16 & .14 \\
\hline \multirow{6}{*}{$\begin{array}{l}\text { Multiplier } \\
\text { needed for } \\
\text { power to } \\
\text { equal } 0.8\end{array}$} & Otter trawl & July a & .10936 & 4.03 & 2.85 & 2.33 & 2.02 & 1.74 & 1.23 & 1.01 & .87 & 1.23 & .87 & .71 & .61 & .87 & .61 & .50 & .43 \\
\hline & & Aug. ${ }^{a}$ & .00013 & 6,821 & 4,823 & 3,938 & 3,411 & 2,945 & 2,083 & 1,700 & 1,473 & 2,076 & 1,468 & 1,199 & 1,038 & 1,466 & 1,036 & 846 & 733 \\
\hline & & Sept. & .17648 & 9.67 & 7.34 & 6.37 & 5.83 & 4.18 & 3.17 & 2.75 & 2.52 & 2.94 & 2.23 & 1.94 & 1.77 & 2.08 & 1.58 & 1.37 & 1.25 \\
\hline & Trammel net & July & .18063 & 15.25 & 11.97 & 10.66 & 9.93 & 6.59 & 5.17 & 4.60 & 4.29 & 4.64 & 3.64 & 3.24 & 3.02 & 3.28 & 2.57 & 2.29 & 2.13 \\
\hline & & Aug. ${ }^{a}$ & .05414 & 12.77 & 9.03 & 7.37 & 6.39 & 5.51 & 3.90 & 3.18 & 2.76 & 3.89 & 2.75 & 2.24 & 1.94 & 2.74 & 1.94 & 1.58 & 1.37 \\
\hline & & Sept. ${ }^{a}$ & .54461 & 2.33 & 1.64 & 1.34 & 1.16 & 1.00 & .71 & .58 & .50 & .71 & .50 & .41 & .35 & .50 & .35 & .29 & .25 \\
\hline
\end{tabular}

${ }^{a}$ Models with an initial negative bend variance component estimate and re-estimated using standard Restricted Maximum Likelihood estimation methods. 
Table 22. Summary of the shovelnose sturgeon-adult power, required mean difference, and multiplier needed using current treatment mean difference at different bend/ subsample levels for each gear type and month of the Habitat Assessment Monitoring Program.

[power $=0.8, \alpha=0.05]$

\begin{tabular}{|c|c|c|c|c|c|c|c|c|c|c|c|c|c|c|c|c|c|c|c|}
\hline \multirow{3}{*}{ Parameter } & \multirow{3}{*}{ Gear type } & \multirow{3}{*}{ Month } & \multirow{3}{*}{$\begin{array}{c}\text { Current } \\
\text { model } \\
\text { treatment } \\
\text { difference }\end{array}$} & \multicolumn{16}{|c|}{ Bend/subsample level } \\
\hline & & & & \multicolumn{4}{|c|}{4} & \multicolumn{4}{|c|}{20} & \multicolumn{4}{|c|}{40} & \multicolumn{4}{|c|}{80} \\
\hline & & & & 4 & 8 & 12 & 16 & 4 & 8 & 12 & 16 & 4 & 8 & 12 & 16 & 4 & 8 & 12 & 16 \\
\hline \multirow[t]{6}{*}{ Power } & Otter trawl & July a & 0.03886 & 0.08 & 0.11 & 0.14 & 0.17 & 0.21 & 0.37 & 0.51 & 0.63 & 0.37 & 0.64 & 0.81 & 0.90 & 0.64 & 0.90 & 0.98 & 1.00 \\
\hline & & Aug. ${ }^{a}$ & .07173 & .06 & .08 & .09 & .11 & .13 & .21 & .29 & .37 & .21 & .37 & .52 & .64 & .37 & .64 & .81 & .91 \\
\hline & & Sept. ${ }^{a}$ & .09804 & .08 & .10 & .13 & .16 & .19 & .34 & .47 & .59 & .34 & .59 & .76 & .87 & .59 & .87 & .97 & .99 \\
\hline & Trammel net & July & .20326 & .08 & .11 & .13 & .14 & .23 & .36 & .46 & .54 & .41 & .63 & .75 & .83 & .68 & .90 & .96 & .98 \\
\hline & & Aug. ${ }^{a}$ & .10542 & .22 & .38 & .53 & .65 & .78 & .97 & 1.00 & 1.00 & .97 & 1.00 & 1.00 & 1.00 & 1.00 & 1.00 & 1.00 & 1.00 \\
\hline & & Sept. ${ }^{\text {a }}$ & .21150 & .20 & .36 & .50 & .62 & .74 & .96 & .99 & 1.00 & .96 & 1.00 & 1.00 & 1.00 & 1.00 & 1.00 & 1.00 & 1.00 \\
\hline \multirow{6}{*}{$\begin{array}{l}\text { Difference } \\
\text { needed for } \\
\text { power to } \\
\text { equal } 0.8\end{array}$} & Otter trawl & July $^{\text {a }}$ & .03886 & .22 & .16 & .13 & .11 & .09 & .07 & .05 & .05 & .07 & .05 & .04 & .03 & .05 & .03 & .03 & .02 \\
\hline & & Aug. ${ }^{a}$ & .07173 & .57 & .40 & .33 & .29 & .25 & .17 & .14 & .12 & .17 & .12 & .10 & .09 & .12 & .09 & .07 & .06 \\
\hline & & Sept. ${ }^{a}$ & .09804 & .58 & .41 & .34 & .29 & .25 & .18 & .15 & .13 & .18 & .13 & .10 & .09 & .13 & .09 & .07 & .06 \\
\hline & Trammel net & July & .20326 & 1.09 & .82 & .71 & .64 & .47 & .35 & .31 & .28 & .33 & .25 & .22 & .20 & .23 & .18 & .15 & .14 \\
\hline & & Aug. ${ }^{a}$ & .10542 & .25 & .18 & .15 & .13 & .11 & .08 & .06 & .05 & .08 & .05 & .04 & .04 & .05 & .04 & .03 & .03 \\
\hline & & Sept. ${ }^{a}$ & .21150 & .53 & .37 & .30 & .26 & .23 & .16 & .13 & .11 & .16 & .11 & .09 & .08 & .11 & .08 & .07 & .06 \\
\hline \multirow{6}{*}{$\begin{array}{l}\text { Multiplier } \\
\text { needed for } \\
\text { power to } \\
\text { equal } 0.8\end{array}$} & Otter trawl & July a & .03886 & 5.65 & 3.99 & 3.26 & 2.82 & 2.44 & 1.72 & 1.41 & 1.22 & 1.72 & 1.22 & .99 & .86 & 1.21 & .86 & .70 & .61 \\
\hline & & Aug. ${ }^{a}$ & .07173 & 7.97 & 5.63 & 4.60 & 3.98 & 3.44 & 2.43 & 1.99 & 1.72 & 2.42 & 1.71 & 1.40 & 1.21 & 1.71 & 1.21 & .99 & .86 \\
\hline & & Sept. ${ }^{a}$ & .09804 & 5.95 & 4.21 & 3.44 & 2.98 & 2.57 & 1.82 & 1.48 & 1.28 & 1.81 & 1.28 & 1.05 & .91 & 1.28 & .90 & .74 & .64 \\
\hline & Trammel net & July & .20326 & 5.34 & 4.03 & 3.48 & 3.17 & 2.31 & 1.74 & 1.50 & 1.37 & 1.63 & 1.23 & 1.06 & .96 & 1.15 & .86 & .75 & .68 \\
\hline & & Aug. ${ }^{a}$ & .10542 & 2.39 & 1.69 & 1.38 & 1.19 & 1.03 & .73 & .59 & .51 & .73 & .51 & .42 & .36 & .51 & .36 & .30 & .26 \\
\hline & & Sept. ${ }^{a}$ & .21150 & 2.49 & 1.76 & 1.44 & 1.24 & 1.07 & .76 & .62 & .54 & .76 & .54 & .44 & .38 & .53 & .38 & .31 & .27 \\
\hline
\end{tabular}

${ }^{\text {a }}$ Models with an initial negative bend variance component estimate and re-estimated using standard Restricted Maximum Likelihood estimation methods. 
Table 23. Summary of the shovelnose sturgeon-juvenile power, required mean difference, and multiplier needed using current treatment mean difference at different bend/ subsample levels for each gear type and month of the Habitat Assessment Monitoring Program.

[power $=0.8, \alpha=0.05$ ]

\begin{tabular}{|c|c|c|c|c|c|c|c|c|c|c|c|c|c|c|c|c|c|c|c|}
\hline \multirow{3}{*}{ Parameter } & \multirow{3}{*}{ Gear type } & \multirow{3}{*}{ Month } & \multirow{3}{*}{$\begin{array}{c}\text { Current } \\
\text { model } \\
\text { treatment } \\
\text { difference }\end{array}$} & \multicolumn{16}{|c|}{ Bend/subsample level } \\
\hline & & & & \multicolumn{4}{|c|}{4} & \multicolumn{4}{|c|}{20} & \multicolumn{4}{|c|}{40} & \multicolumn{4}{|c|}{80} \\
\hline & & & & 4 & 8 & 12 & 16 & 4 & 8 & 12 & 16 & 4 & 8 & 12 & 16 & 4 & 8 & 12 & 16 \\
\hline \multirow[t]{6}{*}{ Power } & Otter trawl & July $^{\text {a }}$ & 0.14822 & 0.22 & 0.40 & 0.55 & 0.67 & 0.79 & 0.98 & 1.00 & 1.00 & 0.98 & 1.00 & 1.00 & 1.00 & 1.00 & 1.00 & 1.00 & 1.00 \\
\hline & & Aug. ${ }^{\text {a }}$ & .07187 & .07 & .09 & .11 & .13 & .16 & .27 & .38 & .48 & .27 & .48 & .65 & .77 & .48 & .77 & .91 & .97 \\
\hline & & Sept. & .07844 & .05 & .06 & .06 & .06 & .07 & .08 & .09 & .09 & .09 & .11 & .13 & .14 & .12 & .17 & .21 & .23 \\
\hline & Trammel net & July & .38389 & .09 & .12 & .14 & .15 & .29 & .43 & .52 & .57 & .51 & .71 & .81 & .86 & .80 & .95 & .98 & .99 \\
\hline & & Aug. ${ }^{a}$ & .05128 & .06 & .06 & .07 & .07 & .08 & .12 & .15 & .18 & .12 & .18 & .25 & .32 & .19 & .32 & .45 & .56 \\
\hline & & Sept. ${ }^{a}$ & .33311 & .22 & .40 & .55 & .67 & .79 & .98 & 1.00 & 1.00 & .98 & 1.00 & 1.00 & 1.00 & 1.00 & 1.00 & 1.00 & 1.00 \\
\hline \multirow{6}{*}{$\begin{array}{l}\text { Difference } \\
\text { needed for } \\
\text { power to } \\
\text { equal } 0.8\end{array}$} & Otter trawl & July a & .14822 & .35 & .24 & .20 & .17 & .15 & .11 & .09 & .07 & .11 & .07 & .06 & .05 & .07 & .05 & .04 & .04 \\
\hline & & Aug. ${ }^{a}$ & .07187 & .49 & .35 & .28 & .24 & .21 & .15 & .12 & .11 & .15 & .11 & .09 & .07 & .11 & .07 & .06 & .05 \\
\hline & & Sept. & .07844 & 1.31 & 1.02 & .90 & .83 & .57 & .44 & .39 & .36 & .40 & .31 & .27 & .25 & .28 & .22 & .19 & .18 \\
\hline & Trammel net & July & .38389 & 1.78 & 1.40 & 1.25 & 1.16 & .77 & .60 & .54 & .50 & .54 & .43 & .38 & .35 & .38 & .30 & .27 & .25 \\
\hline & & Aug. ${ }^{a}$ & .05128 & .63 & .45 & .36 & .32 & .27 & .19 & .16 & .14 & .19 & .14 & .11 & .10 & .14 & .10 & .08 & .07 \\
\hline & & Sept. ${ }^{a}$ & .33311 & .78 & .55 & .45 & .39 & .34 & .24 & .19 & .17 & .24 & .17 & .14 & .12 & .17 & .12 & .10 & .08 \\
\hline \multirow{6}{*}{$\begin{array}{l}\text { Multiplier } \\
\text { needed for } \\
\text { power to } \\
\text { equal } 0.8\end{array}$} & Otter trawl & July a & .14822 & 2.34 & 1.65 & 1.35 & 1.17 & 1.01 & .71 & .58 & .50 & .71 & .50 & .41 & .36 & .50 & .36 & .29 & .25 \\
\hline & & Aug. ${ }^{a}$ & .07187 & 6.81 & 4.82 & 3.93 & 3.40 & 2.94 & 2.08 & 1.70 & 1.47 & 2.07 & 1.47 & 1.20 & 1.04 & 1.46 & 1.03 & .84 & .73 \\
\hline & & Sept. & .07844 & 16.72 & 12.98 & 11.46 & 10.62 & 7.22 & 5.60 & 4.95 & 4.58 & 5.09 & 3.95 & 3.49 & 3.23 & 3.59 & 2.79 & 2.46 & 2.28 \\
\hline & Trammel net & July & .38389 & 4.65 & 3.65 & 3.24 & 3.02 & 2.01 & 1.57 & 1.40 & 1.31 & 1.41 & 1.11 & .99 & .92 & 1.00 & .78 & .70 & .65 \\
\hline & & Aug. ${ }^{\text {a }}$ & .05128 & 12.31 & 8.71 & 7.11 & 6.16 & 5.32 & 3.76 & 3.07 & 2.66 & 3.75 & 2.65 & 2.16 & 1.87 & 2.65 & 1.87 & 1.53 & 1.32 \\
\hline & & Sept. ${ }^{a}$ & .33311 & 2.34 & 1.65 & 1.35 & 1.17 & 1.01 & .71 & .58 & .51 & .71 & .50 & .41 & .36 & .50 & .36 & .29 & .25 \\
\hline
\end{tabular}

${ }^{a}$ Models with an initial negative bend variance component estimate and re-estimated using standard Restricted Maximum Likelihood estimation methods. 
Table 24. Summary of the sicklefin chub-all power, required mean difference, and multiplier needed using current treatment mean difference at different bend/subsample levels for each gear type and month of the Habitat Assessment Monitoring Program.

[power $=0.8, \alpha=0.05]$

\begin{tabular}{|c|c|c|c|c|c|c|c|c|c|c|c|c|c|c|c|c|c|c|c|}
\hline \multirow{3}{*}{ Parameter } & \multirow{3}{*}{ Gear type } & \multirow{3}{*}{ Month } & \multirow{3}{*}{$\begin{array}{c}\text { Current } \\
\text { model } \\
\text { treatment } \\
\text { difference }\end{array}$} & \multicolumn{16}{|c|}{ Bend/subsample level } \\
\hline & & & & \multicolumn{4}{|c|}{4} & \multicolumn{4}{|c|}{20} & \multicolumn{4}{|c|}{40} & \multicolumn{4}{|c|}{80} \\
\hline & & & & 4 & 8 & 12 & 16 & 4 & 8 & 12 & 16 & 4 & 8 & 12 & 16 & 4 & 8 & 12 & 16 \\
\hline \multirow[t]{3}{*}{ Power } & Otter trawl & July a & 0.77769 & 0.09 & 0.12 & 0.16 & 0.20 & 0.25 & 0.45 & 0.61 & 0.74 & 0.45 & 0.74 & 0.89 & 0.96 & 0.74 & 0.96 & 0.99 & 1.00 \\
\hline & & Aug. ${ }^{a}$ & .18626 & .12 & .18 & .25 & .32 & .40 & .68 & .85 & .93 & .68 & .93 & .99 & 1.00 & .93 & 1.00 & 1.00 & 1.00 \\
\hline & & Sept. ${ }^{b}$ & .04943 & .14 & .19 & .23 & .25 & .55 & .74 & .83 & .87 & .85 & .96 & .99 & .99 & .99 & 1.00 & 1.00 & 1.00 \\
\hline Difference & Otter trawl & July a & .77769 & 3.89 & 2.75 & 2.24 & 1.94 & 1.68 & 1.19 & .97 & .84 & 1.18 & .84 & .68 & .59 & .83 & .59 & .48 & .42 \\
\hline needed for & & Aug. ${ }^{a}$ & .18626 & .70 & .50 & .41 & .35 & .30 & .21 & .18 & .15 & .21 & .15 & .12 & .11 & .15 & .11 & .09 & .08 \\
\hline power to & & Sept. ${ }^{b}$ & .04943 & .16 & .13 & .11 & .11 & .07 & .05 & .05 & .04 & .05 & .04 & .03 & .03 & .03 & .03 & .02 & .02 \\
\hline equal 0.8 & & & & & & & & & & & & & & & & & & & \\
\hline Multiplier & Otter trawl & July $^{a}$ & .77769 & 5.00 & 3.53 & 2.89 & 2.50 & 2.16 & 1.53 & 1.25 & 1.08 & 1.52 & 1.08 & .88 & .76 & 1.07 & .76 & .62 & .54 \\
\hline needed for & & Aug. ${ }^{a}$ & .18626 & 3.78 & 2.67 & 2.18 & 1.89 & 1.63 & 1.15 & .94 & .82 & 1.15 & .81 & .66 & .57 & .81 & .57 & .47 & .41 \\
\hline power to & & Sept. ${ }^{b}$ & .04943 & 3.22 & 2.58 & 2.32 & 2.18 & 1.34 & 1.07 & .96 & .91 & .94 & .75 & .68 & .64 & .66 & .53 & .48 & .45 \\
\hline
\end{tabular}

\footnotetext{
${ }^{a}$ Models with an initial negative bend variance component estimate and re-estimated using standard Restricted Maximum Likelihood estimation methods.
}

${ }^{\mathrm{b}}$ Models with the treated mean response of zero. 
Table 25. Summary of the speckled chub-all power, required mean difference, and multiplier needed using current treatment mean difference at different bend/subsample levels for each gear type and month of the Habitat Assessment Monitoring Program.

[power $=0.8, \alpha=0.05]$

\begin{tabular}{|c|c|c|c|c|c|c|c|c|c|c|c|c|c|c|c|c|c|c|c|}
\hline \multirow{3}{*}{ Parameter } & \multirow{3}{*}{ Gear type } & \multirow{3}{*}{ Month } & \multirow{3}{*}{$\begin{array}{c}\text { Current } \\
\text { model } \\
\text { treatment } \\
\text { difference }\end{array}$} & \multicolumn{16}{|c|}{ Bend/subsample level } \\
\hline & & & & \multicolumn{4}{|c|}{4} & \multicolumn{4}{|c|}{20} & \multicolumn{4}{|c|}{40} & \multicolumn{4}{|c|}{80} \\
\hline & & & & 4 & 8 & 12 & 16 & 4 & 8 & 12 & 16 & 4 & 8 & 12 & 16 & 4 & 8 & 12 & 16 \\
\hline \multirow[t]{5}{*}{ Power } & Mini-fyke net & Aug. ${ }^{a}$ & 0.08107 & 0.14 & 0.20 & 0.24 & 0.27 & 0.53 & 0.75 & 0.85 & 0.89 & 0.83 & 0.96 & 0.99 & 1.00 & 0.98 & 1.00 & 1.00 & 1.00 \\
\hline & & Sept. & .02791 & .06 & .06 & .07 & .07 & .08 & .11 & .14 & .17 & .12 & .18 & .24 & .30 & .19 & .32 & .43 & .53 \\
\hline & Otter trawl & July b & .10546 & .12 & .19 & .27 & .34 & .43 & .71 & .87 & .94 & .71 & .95 & .99 & 1.00 & .95 & 1.00 & 1.00 & 1.00 \\
\hline & & Aug. & .13058 & .06 & .08 & .09 & .10 & .13 & .20 & .26 & .31 & .21 & .35 & .46 & .55 & .37 & .60 & .75 & .84 \\
\hline & & Sept. & .41236 & .06 & .06 & .07 & .07 & .10 & .13 & .14 & .15 & .15 & .21 & .24 & .26 & .25 & .36 & .43 & .47 \\
\hline \multirow{5}{*}{$\begin{array}{l}\text { Difference } \\
\text { needed for } \\
\text { power to } \\
\text { equal } 0.8\end{array}$} & Mini-fyke net & Aug. ${ }^{a}$ & .08107 & .27 & .21 & .18 & .17 & .11 & .09 & .08 & .07 & .08 & .06 & .05 & .05 & .06 & .04 & .04 & .04 \\
\hline & & Sept. & .02791 & .35 & .25 & .21 & .19 & .15 & .11 & .09 & .08 & .10 & .07 & .06 & .05 & .07 & .05 & .04 & .04 \\
\hline & Otter trawl & July $^{\mathrm{b}}$ & .10546 & .38 & .27 & .22 & .19 & .17 & .12 & .10 & .08 & .12 & .08 & .07 & .06 & .08 & .06 & .05 & .04 \\
\hline & & Aug. & .13058 & 1.05 & .77 & .65 & .58 & .45 & .33 & .28 & .25 & .32 & .23 & .20 & .18 & .22 & .16 & .14 & .12 \\
\hline & & Sept. & .41236 & 4.16 & 3.35 & 3.03 & 2.86 & 1.79 & 1.45 & 1.31 & 1.24 & 1.26 & 1.02 & .92 & .87 & .89 & .72 & .65 & .61 \\
\hline \multirow{5}{*}{$\begin{array}{l}\text { Multiplier } \\
\text { needed for } \\
\text { power to } \\
\text { equal } 0.8\end{array}$} & Mini-fyke net & Aug. ${ }^{a}$ & .08107 & 3.31 & 2.57 & 2.26 & 2.10 & 1.38 & 1.07 & .94 & .87 & .97 & .75 & .66 & .61 & .68 & .53 & .47 & .43 \\
\hline & & Sept. & .02791 & 12.64 & 9.12 & 7.60 & 6.71 & 5.25 & 3.79 & 3.16 & 2.79 & 3.69 & 2.66 & 2.22 & 1.96 & 2.60 & 1.88 & 1.56 & 1.38 \\
\hline & Otter trawl & July $^{\mathrm{b}}$ & .10546 & 3.65 & 2.58 & 2.11 & 1.82 & 1.58 & 1.11 & .91 & .79 & 1.11 & .79 & .64 & .56 & .78 & .55 & .45 & .39 \\
\hline & & Aug. & .13058 & 8.01 & 5.86 & 4.94 & 4.41 & 3.46 & 2.53 & 2.13 & 1.90 & 2.44 & 1.78 & 1.50 & 1.34 & 1.72 & 1.26 & 1.06 & .95 \\
\hline & & Sept. & .41236 & 10.08 & 8.12 & 7.35 & 6.94 & 4.35 & 3.51 & 3.18 & 3.00 & 3.07 & 2.47 & 2.24 & 2.11 & 2.17 & 1.75 & 1.58 & 1.49 \\
\hline
\end{tabular}

${ }^{a}$ Models with the treated mean response of zero.

${ }^{\mathrm{b}}$ Models with an initial negative bend variance component estimate and re-estimated using standard Restricted Maximum Likelihood estimation methods. 
Table 26. Summary of the sturgeon chub-all power, required mean difference, and multiplier needed using current treatment mean difference at different bend/subsample levels for each gear type and month of the Habitat Assessment Monitoring Program.

[power $=0.8, \alpha=0.05]$

\begin{tabular}{|c|c|c|c|c|c|c|c|c|c|c|c|c|c|c|c|c|c|c|c|}
\hline \multirow{3}{*}{ Parameter } & \multirow{3}{*}{ Gear type } & \multirow{3}{*}{ Month } & \multirow{3}{*}{$\begin{array}{c}\text { Current } \\
\text { model } \\
\text { treatment } \\
\text { difference }\end{array}$} & \multicolumn{16}{|c|}{ Bend/subsample level } \\
\hline & & & & \multicolumn{4}{|c|}{4} & \multicolumn{4}{|c|}{20} & \multicolumn{4}{|c|}{40} & \multicolumn{4}{|c|}{80} \\
\hline & & & & 4 & 8 & 12 & 16 & 4 & 8 & 12 & 16 & 4 & 8 & 12 & 16 & 4 & 8 & 12 & 16 \\
\hline \multirow[t]{4}{*}{ Power } & Mini-fyke net & Sept. & 0.08587 & 0.14 & 0.20 & 0.23 & 0.26 & 0.63 & 0.81 & 0.88 & 0.92 & 0.91 & 0.98 & 0.99 & 1.00 & 1.00 & 1.00 & 1.00 & 1.00 \\
\hline & Otter trawl & July a & .00154 & .05 & .05 & .05 & .05 & .05 & .05 & .05 & .05 & .05 & .05 & .05 & .05 & .05 & .05 & .06 & .06 \\
\hline & & Aug. & .02015 & .05 & .05 & .05 & .05 & .05 & .06 & .06 & .07 & .06 & .07 & .08 & .09 & .07 & .09 & .10 & .12 \\
\hline & & Sept. & .00270 & .05 & .05 & .05 & .05 & .05 & .05 & .05 & .05 & .05 & .05 & .05 & .05 & .05 & .05 & .05 & .05 \\
\hline Difference & Mini-fyke net & Sept. & .08587 & .28 & .22 & .20 & .19 & .11 & .08 & .08 & .07 & .07 & .06 & .05 & .05 & .05 & .04 & .04 & .04 \\
\hline needed for & Otter trawl & July a & .00154 & .15 & .10 & .08 & .07 & .06 & .04 & .04 & .03 & .04 & .03 & .03 & .02 & .03 & .02 & .02 & .02 \\
\hline power to & & Aug. & .02015 & .66 & .47 & .38 & .34 & .28 & .20 & .17 & .15 & .20 & .14 & .12 & .10 & .14 & .10 & .08 & .07 \\
\hline equal 0.8 & & Sept. & .00270 & .44 & .34 & .30 & .27 & .19 & .15 & .13 & .12 & .13 & .10 & .09 & .08 & .09 & .07 & .06 & .06 \\
\hline Multiplier & Mini-fyke net & Sept. & .08587 & 3.21 & 2.57 & 2.32 & 2.19 & 1.23 & .98 & .89 & .83 & .86 & .69 & .62 & .58 & .60 & .48 & .43 & .41 \\
\hline needed for & Otter trawl & Julya & .00154 & 95.03 & 67.20 & 54.87 & 47.52 & 41.03 & 29.02 & 23.69 & 20.52 & 28.92 & 20.45 & 16.70 & 14.46 & 20.42 & 14.44 & 11.79 & 10.21 \\
\hline power to & & Aug. & .02015 & 32.52 & 23.19 & 19.09 & 16.67 & 14.04 & 10.01 & 8.24 & 7.20 & 9.90 & 7.06 & 5.81 & 5.07 & 6.99 & 4.98 & 4.10 & 3.58 \\
\hline equal 0.8 & & Sept. & .00270 & 161.93 & 125.09 & 110.11 & 101.79 & 69.92 & 54.01 & 47.54 & 43.95 & 49.28 & 38.07 & 33.51 & 30.98 & 34.79 & 26.88 & 23.66 & 21.87 \\
\hline
\end{tabular}

${ }^{\text {a }}$ Models with an initial negative bend variance component estimate and re-estimated using standard Restricted Maximum Likelihood estimation methods. 
Publishing support provided by:

Rolla Publishing Service Center

For more information concerning this publication, contact:

Director, USGS Columbia Environmental Research Center 4200 New Haven Road

Columbia, M0 65201

(573) 875-5399

Or visit the Columbia Environmental Research Center Web site at: http://www.cerc.usgs.gov 


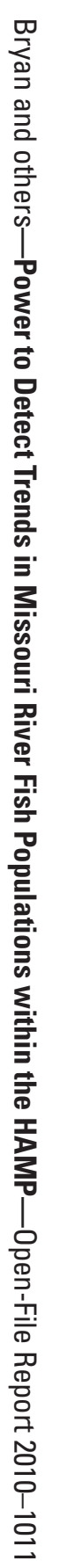

